\title{
MODEL JARINGAN SYARAF TIRUAN DALAM MEMPREDIKSI JUMLAH PRODUKSI TELUR AYAM PETELUR BERDASARKAN PROVINSI DI INDONESIA
}

\author{
Pipit Mutiara Putri'1), Devi Monika ${ }^{2)}$, Lulu Apriliani' ${ }^{3)}$,Solikhun ${ }^{4)}$ \\ 1,2,3,4 Program Studi Manajemen Informatika, AMIK Tunas Bangsa Pematangsiantar \\ 1,2,3,4 Jln. Jenderal Sudirman Blok A No. 1,2,3 Pematangsiantar \\ Email: ${ }^{1}$ pmp09051999@gmail.com, ${ }^{2}$ Monicadevi501@gmail.com, ${ }^{3}$ luluapriliani3004@gmail.com, \\ ${ }^{4}$ solikhun@amiktunasbangsa.ac.id
}

\begin{abstract}
Improving human resources cannot be achieved without adequate nutrition. To educate, strengthen and improve the achievements of Indonesian people, much depends on fulfilling good nutrition, especially animal protein such as meat, milk and eggs (Anonymous, 1990).Eggs are one product that can meet some of the nutritional needs of the community. These livestock products also have the potential to be developed optimally, because in addition to the price that is relatively cheap compared to other animal proteins, the business is also relatively easy and even though it is cultivated in small-scale businesses it can increase income and expand employment opportunities (Anonymous, 1994). The data used is data from the National Statistics Agency through the website www.bps.go.id. The data is data on the number of egg production of laying hens based on the provinces in 2010 to 2017. The algorithms used in this study are Artificial Neural Networks with the Backpropogation method. The input variables used are data for 2010 (X1), data for 2011 (X2), data for 2012 (X3), data for 2013 (X4), data for 2014 (X5) data for 2015 (X6) and data in 2016 (X7) with a training and testing architecture model of 4 architectures namely 7-4-1, 7-8-1, 7-16-1dan 7-32-1. Target data is taken from 2017 data. The output produced is the best pattern of ANN architecture. The best architectural model is 32-1 with MSE 0.0082336 and an accuracy rate of $96.88 \%$. From this model, the prediction of egg production of laying hens is based on the province of each province in Indonesia.
\end{abstract}

Keywords: Laying Egg Production, ANN, Backpropogation and Prediction

\footnotetext{
Abstrak

Peningkatan sumber daya manusia tidak mungkin tercapai tanpa gizi yang cukup. Untuk mencerdaskan dan meningkatkan prestasi masyarakat di Indonesia, banyak bergantung pada pemenuhan gizi yang baik terutama protein hewani seperti daging, susu dan telur. Telur merupakan salah satu produk yang dapat
}

memenuhi sebagian kebutuhan gizi masyarakat. Produk hasil ternak ini juga mempunyai potensi untuk dikembangkan secara optimal, karena disamping harganya yang relative murah dibanding protein hewani yang lainnya, pengusahannya juga relative mudah dan walaupun diusahakan dalam usaha skala kecil mampu meningkatkan pendapatan dan memperluas kesempatan kerja. Dengan menggunakan data dari Badan Pusat Statistik Nasional melalui website www.bps.go.id didapat data jumlah produksi telur ayam petelur berdasarkan provinsi tahun 2010 sampai dengan tahun 2017. Algoritma yang digunakan pada penelitian ini adalah Jaringan Saraf Tiruan dengan metode Backpropogation. dengan model arsitektur pelatihan dan pengujian sebanyak 4 arsitektur yakni 7-4-1, 7-8-1 ,7-16-1dan 7-32-1. Data target diambil dari data tahun 2017. Keluaran yang dihasilkan adalah pola terbaik dari arsitektur JST. Model arsitektur terbaik adalah 7-32-1 dengan MSE 0,0082336 dan tingkat akurasi 96.88\%. Dari model ini maka dihasilkan prediksi jumlah produksi telur ayam petelur berdasarkan provinsi dari masing-masing provinsi di Indonesia.

Kata Kunci:Produksi Telur Ayam Petelur, JST, Backpropogation dan Prediksi

\section{Pendahuluan}

Peningkatan sumber daya manusia tidak mungkin tercapai tanpa gizi yang cukup. Untuk mencerdaskan, memperkokoh dan meningkatkan prestasi manusia Indonesia, banyak bergantung pada pemenuhan gizi yang baik terutama protein hewani seperti daging, susu dan telur. Telur merupakan salah satu produk yang dapat memenuhi sebagian kebutuhan gizi masyarakat. Produk hasil ternak ini juga mempunyai potensi untuk dikembangkan secara optimal, karena disamping harganya yang relative murah dibanding protein hewani yang lainnya, pengusahannya juga relative mudah dan walaupun diusahakann dalam usaha skala kecil mampu meningkatkan pendapatan dan memperluas kesempatan kerja . 
Pada penelitian terbaru telah ditemukan bahwa lemak pada telur adalah jenis tidak jenuh (unsaturated), meskipun terdapat juga kolestrol jahat namun lebih banyak berisi kolestrol baik. Saat ini banyak ditemukan telur dengan stempel rendah kolestrol (telur renkoles). Pertimbangan pentingnya telur tersebut, Pemerintah selalu berupaya untuk meningkatkan ketahanan pangan terutama yang bersumber dari peningkatan produksi dalam negeri. Pertimbangan tersebut menjadi semakin penting bagi Indonesia karena jumlah penduduknya semakin besar dengan sebaran populasi yang luas dan cakupan geografis yang tersebar. Tercatat dari sejak tahun 2010 hingga tahun 2017 produksi telur di Indonesia terus mengalami peningkatan. Tidak hanya dalam skala nasional tapi juga berdasarkan provinsi juga terlihat jelas bahwa produk telur terus mengalami peningkatan.

Untuk menstabilkan persediaan dan harga Telur ayam, maka pemerintah harus mengetahui berapa produksi dalam negeri. Dengan mengetahui beberapa persediaan produksi telur ayam, hal ini akan mengurangi resiko kelebihan import telur ayam dari luar negeri sehingga dapat menghemat uang Negara.

Melihat permasalahan yang cukup kompleks tersebut, tentunya dibutuhkan suatu metode yang dapat lebih efektif dalam memprediksi jumlah produksi telur ayam petelur berdasarkan provinsi dalam pemenuhan kebutuhan bahan masak pangan di Indonesia. Adapun metode yang akan digunakan dalam memprediksi jumlah produksi telur ayam petelur berdasarkan provinsi di Indonesia penelitian menggunakan metode Jaringan Syaraf Tiruan (JST) . Dan peneliti dalam penerapannya menggunakan sebuah teknik peramalan yang dapat digunakan untuk melakukan prediksi yaitu backpropogation. Dengan menggunakan teknik ini dimaksudkan untuk membuat sebuah sistem yang dapat memprediksi jumlah produksi telur ayam berdasarkan provinsi di Indonesia. Diharapka melalui sistem ini dapat membantu pemerintah dalam meningkatkan ketahanan pangan di Indonesia khususnya produksi telur ayam petelur .

\section{Metode}

\subsection{Kecerdasan Buatan (Artificial Intelegent)}

Kecerdasan Buatan (Artificial Intelligence atau AI) didefinisikan sebagai kecerdasan yang ditunjukkan oleh suatu entitas buatan. Sistem seperti ini umumnya dianggap komputer. Kecerdasan diciptakan dan dimasukkan ke dalam suatu mesin (komputer) agar dapat melakukan pekerjaan seperti yang dapat dilakukan manusia. Kecerdasan Buatan (Artificial Intelligence atau AI) didefinisikan sebagai kecerdasan yang ditunjukkan oleh suatu entitas buatan. Sistem seperti ini umumnya dianggap komputer. Kecerdasan diciptakan dan dimasukkan ke dalam suatu mesin (komputer) agar dapat melakukan pekerjaan seperti yang dapat dilakukan manusia. AI adalah bidang studi berdasarkan pada premis bahwa pikiran cerdas dapat dianggap sebagai bentuk perhitungan [1].

\subsection{Jaringan Saraf Tiruan}

Jaringan syaraf tiruan (JST) adalah paradigm pemrosesan suatu informasi Yang terinspirasi oleh sistem sel syaraf biologi. Jaringan ini biasanya menggunakan komponen elektronik atau disimulasikan pada aplikasi computer [2].

\subsection{Algoritma Backpropogation}

Pendekatan jaringan saraf tiruan dapat meniru perilaku yang kompleks dan non-linear melalui neuron, dan telah banyak digunakan dalam prediksi. Model yang paling banyak digunakan pada kecerdasan buatan adalah model backpropagation. Ciri khas backpropagation melibatkan tiga lapisan : lapisan input, dimana data diperkenalkan ke jaringan; hidden layer, dimana data diproses; dan lapisan output, di mana hasil dari masukan yang diberikan oleh lapisan input [3].

\subsection{Arsitektur Jaringan Backpropagation}

JST propagasi balik adalah JST dengan topologi multi-lapis (multilayer) dengan satu lapis masukan (lapis $X$ ), satu atau lebih lapis hidden atau tersembunyi (lapis $Z$ ) dan satu lapis keluaran (lapis $Y$ ). Setiap lapis memiliki neuron-neuron (unit-unit) yang dimodelkan dengan lingkaran (lihat Gambar 1). Di antara neuron pada satu lapis dengan neuron pada lapis berikutnya dihubungkan dengan model koneksi yang memiliki bobot-bobot (weights), w dan v. Lapis tersembunyi dapat memiliki bias, yang memiliki bobot sama dengan satu [4] 


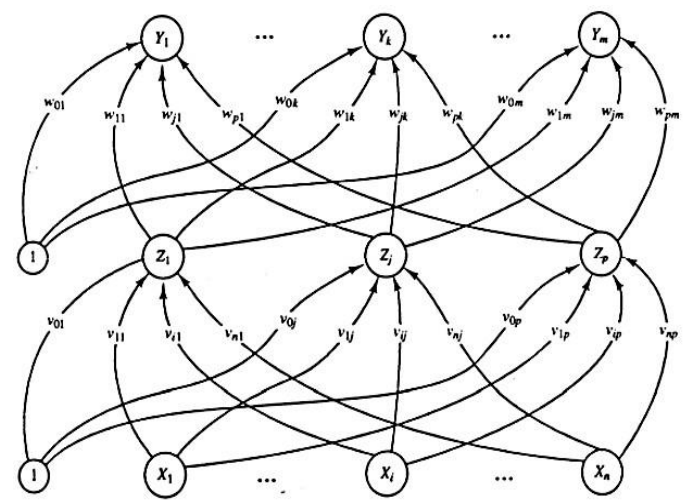

Gambar 1. Arsitektur jaringan backpropagation

\subsection{Langkah-Langkah Jaringan Saraf Tiruan Backpropagation}

Langkah-langkah dalam Jaringan Saraf Tiruan

Backpropagation meliputi tiga fase yaitu :

1. Fase I : Propagasi Maju

Selama propagasi maju, sinyal masukan $(=x i)$ dipropagasikan ke lapis tersembunyi menggunakan fungsi aktivasi yang ditentukan. Keluaran dari setiap unit lapis tersembunyi (= zj) tersebut selanjutnya dipropagasikan maju lagi ke lapis tersembunyi di atasnya menggunakan fungsi aktivasi yang ditentukan. Demikian seterusnya hingga menghasilkan keluaran jaringan $(=y k)$. Berikutnya, keluaran jaringan (= $y k)$ dibandingkan dengan target yang harus dicapai $(=t k)$. Selisih $t k-y k$ adalah kesalahan yang terjadi. Jika kesalahan ini lebih kecil dari batas toleransi yang ditentukan, maka iterasi dihentikan. Akan tetapi apabila kesalahan masih lebih besar dari batas toleransinya, maka bobot setiap garis dalam jaringan akan dimodifikasikan untuk mengurangi kesalahan yang terjadi.

2. Fase II : Propagasi Mundur

Berdasarkan kesalahan $t k-y k$, dihitung faktor $\delta k$ $(k=1, \quad 2, \quad \ldots, \quad m)$ yang dipakai untuk mendistribusikan kesalahan di unit $y k$ ke semua unit tersembunyi yang terhubung langsung dengan $y k$. $\delta k$ juga dipakai untuk mengubah bobot garis yang menghubungkan langsung dengan unit keluaran. Dengan cara yang sama, dihitung $\delta j$ di setiap unit di lapis tersembunyi sebagai dasar perubahan bobot semua garis yang berasal dari unit tersembunyi di lapis di bawahnya. Demikian seterusnya hingga faktor $\delta$ di unit tersembunyi yang berhubungan langsung dengan unit masukan dihitung.

3. Fase III : Perubahan Bobot

Setelah semua faktor $\delta$ dihitung, bobot semua garis dimodifikasi bersamaan. Perubahan bobot suatu garis didasarkan atas faktor $\delta$ neuron di lapis atasnya. Sebagai contoh, perubahan bobot garis yang menuju ke lapis keluaran didasarkan atas dasar $\delta k$ yang ada di unit keluaran. Ketiga fase tersebut diulang ulang terus hingga kondisi penghentian dipenuhi. Umumnya kondisi penghentian yang sering dipakai adalah jumlah iterasi atau kesalahan. Iterasi akan dihentikan jika jumlah iterasi yang dilakukan sudah melebihi jumlah maksimum iterasi yang ditetapkan, atau jika kesalahan yang terjadi sudah lebih kecil dari batas toleransi yang diijinkan[5].

Algoritma pelatihan untuk jaringan Backpropagation dengan satu layar tersembunyi (dengan fungsi aktivasi sigmoid biner) adalah[6]:

Langkah 0 : Inisialisasi semua bobot dengan bilangan acak kecil.

Langkah 1 : Jika kondisi penghentian belum dipenuhi, lakukan langkah 2-8.

Langkah 2 : Untuk setiap pasang data pelatihan, lakukan langkah 3-8.

Langkah $3 \quad$ : Langkah 3 (langkah 3-5 merupakan fase 1).

Tiap unit masukan menerima sinyal dan meneruskannya ke unit tersembunyi diatasnya.

Langkah 4 : Hitung semua keluaran di unit tersembunyi $z j(j=1,2, \ldots, p)$.

$$
\begin{aligned}
Z_{-} \text {net }_{j}=V_{j 0} & +\sum_{i=1}^{n} X_{i} V_{j i} \\
Z_{j} & =f\left(Z_{-} \text {net }_{j}\right)=\frac{1}{1+\exp ^{\left(- \text {znnet }_{j}\right)}}
\end{aligned}
$$

Langkah 5 : Hitung semua keluaran jaringan di unit keluaran $y k(k=1,2, \ldots, m)$

$$
y_{\text {net }}=W_{k 0}+\sum_{j=1}^{p} Z_{j} W_{k j}
$$

Menghitung kembali sesuai dengan fungsi aktivasi:

$$
\begin{gathered}
y_{k}=f\left(y_{-} \text {net }_{k j}\right) \\
\left.Z_{j}=\frac{1}{1+\exp \left(-y, n s t_{k}\right)}\right)
\end{gathered}
$$

Langkah $6 \quad$ : (langkah 6-7 merupakan fase 2) Hitung faktor $\delta$ unit keluaran berdasarkan kesalahan di setiap unit keluaran $y k(k=1,2, \ldots, m)$.

$$
\begin{gathered}
\delta_{k}=\left(t_{k}-y_{k}\right) f^{\prime}\left(y_{n} n_{e} t_{k}\right)= \\
\left(t_{k}-y_{k}\right) y_{k}\left(1-y_{k}\right) \\
t_{k}=\text { target }
\end{gathered}
$$

keluaran $\delta k$ merupakan unit kesalahan yang akan dipakai dalam perubahan bobot layar dibawahnya. Hitung perubahan 


$$
\begin{gathered}
\begin{array}{c}
\text { bobot } w k j \quad \text { dengan laju } \\
\text { pemahaman } \alpha .
\end{array} \\
\Delta W_{k j}=\alpha \delta_{k z_{j j}}, k=1,2, \ldots, m, j=0,1, \\
\ldots, p
\end{gathered}
$$

Langkah $7 \quad$ : Hitung faktor $\delta$ unit tersembunyi berdasarkan kesalahan di setiap unit tersembunyi $z j(j=1,2, \ldots, p)$

$$
\delta_{\text {net }_{j}}=\sum_{k=1}^{m} \delta_{k} W_{k j}
$$

Faktor $\delta$ unit tersembunyi.

$$
\begin{array}{r}
\delta_{j}=\delta_{\text {net }_{j}} f^{\prime}\left(z_{-} \text {net }_{j}\right)=\delta_{\text {net }_{j}} z_{j}\left(1-z_{j}\right) \\
\text { Hitung suku perubahan bobot vji. } \\
\Delta V_{j \mathrm{i}}=\alpha \delta_{j} x_{i}, j=1,2, \ldots, p, i=0,1, \ldots, n
\end{array}
$$

Langkah 8 : Hitung semua perubahan bobot. Perubahan bobot garis yang menuju ke unit keluaran, yaitu

$W_{k j}($ baru $)=W_{k j}($ lama $)+\Delta W_{k j j}$
$k=1,2, \ldots, m, j=0,1, \ldots, p n$

Perubahan bobot garis yang menuju ke unit tersembunyi, yaitu:

$V_{j \mathrm{i}}($ baru $)=V_{j \mathrm{i}}($ lama $)+\Delta V_{j \mathrm{i}}$,

$j=1,2, \ldots, p, i=0,1, \ldots, n$

\subsection{Karakteristik Jaringan Saraf Tiruan}

Jaringan Saraf Tiruan memiliki beberapa karakteristik yang unik, diantaranya adalah :

1. Kemampuan untuk belajar

2. Kemampuan untuk mengeneralisasi

3. Kemampuan untuk menyolusikan permasalahan yang tidak bisa atau kurang baik bila dimodelkan sebagai sistem linier, yang menjadi persyaratan pada beberapa metode peramalan lainnya, seperti model data deret waktu (time series model).

\subsection{Perancangan Sistemedr}

\section{Hasil Dan Pembahasan}

\subsubsection{Pendefinisian Input dan Target}

Data Jumlah Produksi Telur Ayam Petelur Berdasarkan Provinsi akan diolah oleh Jaringan Saraf Tiruan dengan metode backpropogation. Agar data dapat dikenali oleh Jaringan Saraf Tiruan, maka data harus direpresentasikan ke dalam bentuk numerik antara 0 sampai dengan 1 , baik variabel maupun isinya yang merupakan masukan data Data Jumlah Produksi Telur Ayam Petelur sebagai pengenalan pola dan keluaran yang merupakan prediksi Data Jumlah Produksi Telur Ayam Petelur yang diperoleh dari model arsitektur terbaik pada saat penentuan pola terbaik. Hal ini dikarenakan jaringan menggunakan fungsi aktivasi sigmoid biner (logsig) yang rangenya dari 0 sampai 1. Nilai-nilai yang digunakan diperoleh berdasarkan kategori dari masing-masing variabel selain juga untuk memudahkan mengingat dalam pendefinisiannya.

\subsubsection{Pendefinisian Input}

Variabel Jumlah Produksi Telur Ayam Petelur Berdasarkan Provinsi di Indonesia adalah kriteria yang menjadi acuan dalam pengambilan keputusan pada penilaian dengan menggunakan Jaringan Saraf Tiruan. Variabel ditentukan dengan cara melihat ketergantungan data terhadap penelitian yang dilakukan. Kriteria yang digunakan berdasarkan data dari Badan Pusat Statistik Nasional (Online: www.bps.go.id). Adapun daftar variabel dalam memprediksi Data Jumlah Produksi Telur Ayam Petelur tabel 1:

Tabel 1. Daftar Kriteria Jumlah Produksi Telur Ayam Petelur Berdasarkan Provinsi di Indonesia

\begin{tabular}{ccc}
\hline No & Variabel & Nama Kriteria \\
\hline 1 & X1 & Data Tahun 2010 \\
2 & X2 & Data Tahun 2011 \\
3 & X3 & Data Tahun 2012 \\
4 & X4 & Data Tahun 2013 \\
5 & X5 & Data Tahun 2014 \\
6 & X6 & Data Tahun 2015 \\
7 & X7 & Data Tahun 2016 \\
8 & Target & Data Tahun 2017 \\
\hline & Sumber : Badan Pusat Statistik Nasional
\end{tabular}

Data input diperoleh dari website Badan Pusat Statistik Nasional tentang Memprediksi Jumlah Produksi Telur Ayam Petelur Berdasarkan Provinsi di Indonesia. Data sampel yang digunakan adalah data Jumlah Produksi Telur Ayam Petelur Berdasarkan Provinsi Tahun 2010 sampai Tahun 2017 yang terdiri dari 32 provinsi. Masing masing data memiliki 7 variabel dan 1 target. Data ini nantinya akan ditransformasikan ke sebuah data antara 0 sampai 1 sebelum dilakukan pelatihan dan pengujian menggunakan Jaringan Saraf Tiruan metode backpropagation dengan rumus :

$$
x^{\prime}=\frac{0.8(x-a)}{b-a}+0.1
$$

\subsubsection{Pendefinisian Target}

Adapun data target adalah Data Jumlah Produksi Telur Ayam Petelur Berdasarkan Provinsi Tahun 2017

\subsection{Pengolahan Data}

Pengolahan data dilakukan dengan bantuan Matlab R2011a aplikasi perangkat lunak. Sampel Data Jumlah Produksi Telur Ayam Petelur Berdasarkan 
Propinsi. Data ini akan digunakan pada data pelatihan dan data pengujian. Sampel data yang telah diproses dan ditranformasikan adalah sebagai berikut.

Tabel 2. Sampel Data Memprediksi Jumlah Produksi Telur Ayam Petelur Berdasarkan Provinsi di Indonesia

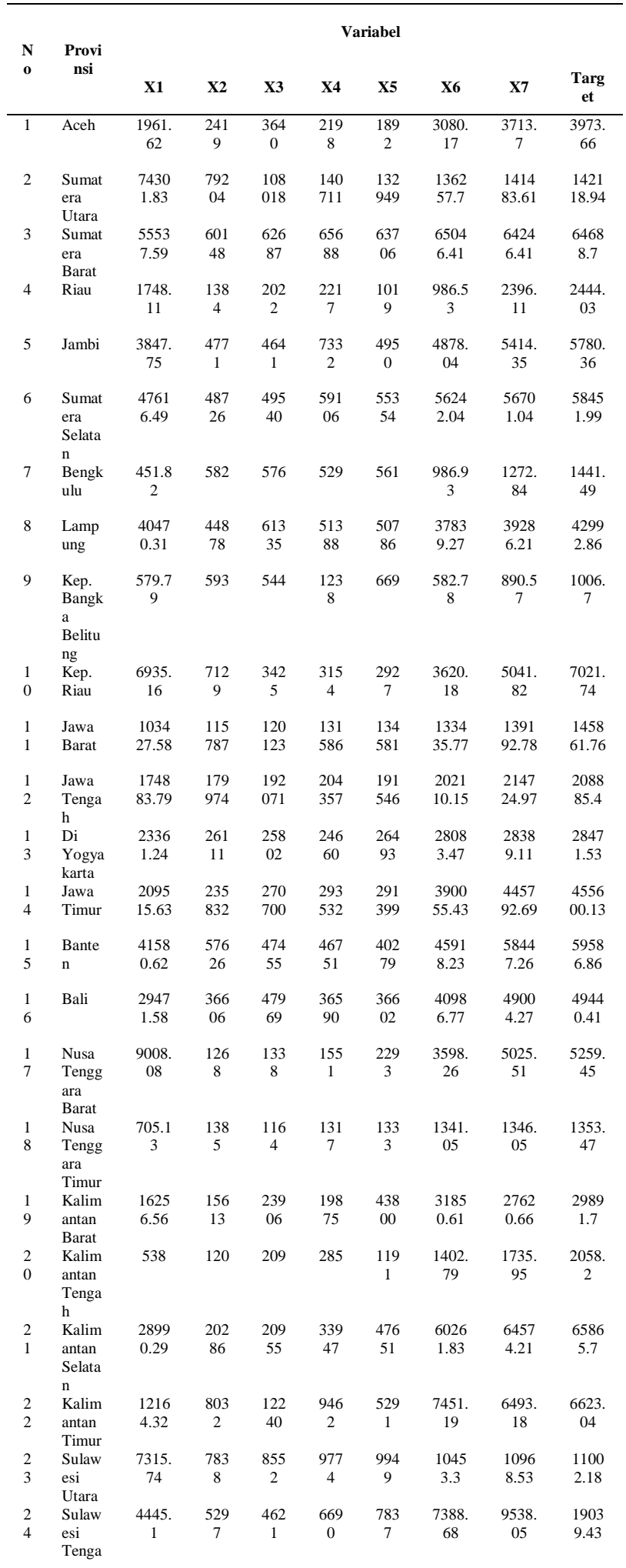

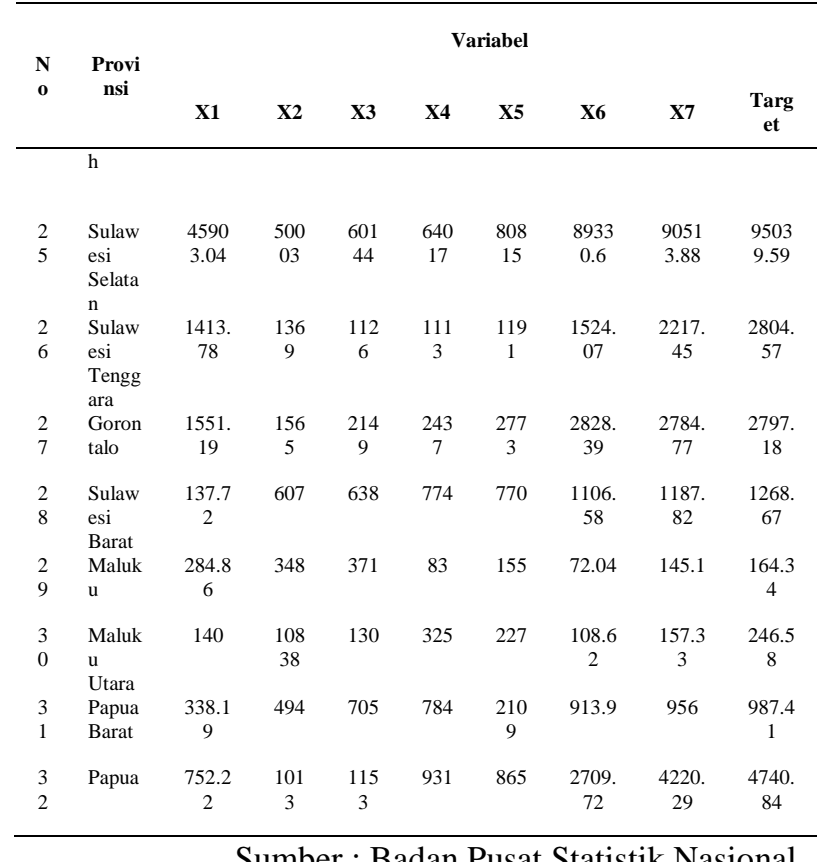

Sumber : Badan Pusat Statistik Nasional

Tabel 3. Sampel dari data yang telah ditransformasikan

\begin{tabular}{|c|c|c|c|c|c|c|c|c|c|}
\hline $\begin{array}{l}\mathbf{N} \\
\mathbf{0}\end{array}$ & $\begin{array}{l}\text { Nama } \\
\text { Data }\end{array}$ & X1 & $\mathrm{X} 2$ & $\mathrm{X3}$ & $\mathrm{X} 4$ & X5 & X6 & X7 & $\begin{array}{l}\text { Tar } \\
\text { get }\end{array}$ \\
\hline 1 & Data 1 & $\begin{array}{r}0.10 \\
332\end{array}$ & $\begin{array}{r}0.10 \\
412\end{array}$ & $\begin{array}{r}0.10 \\
627\end{array}$ & $\begin{array}{r}0.103 \\
73\end{array}$ & $\begin{array}{r}0.10 \\
320\end{array}$ & $\begin{array}{r}0.10 \\
528\end{array}$ & $\begin{array}{r}0.10 \\
640\end{array}$ & $\begin{array}{r}0.10 \\
685\end{array}$ \\
\hline 2 & Data 2 & $\begin{array}{r}0.23 \\
036\end{array}$ & $\begin{array}{r}0.23 \\
897\end{array}$ & $\begin{array}{r}0.28 \\
958\end{array}$ & $\begin{array}{r}0.346 \\
99\end{array}$ & $\begin{array}{r}0.33 \\
336\end{array}$ & $\begin{array}{r}0.33 \\
917\end{array}$ & $\begin{array}{r}0.34 \\
835\end{array}$ & $\begin{array}{r}0.34 \\
946\end{array}$ \\
\hline 3 & Data 3 & $\begin{array}{r}0.19 \\
741\end{array}$ & $\begin{array}{r}0.20 \\
551\end{array}$ & $\begin{array}{r}0.20 \\
996\end{array}$ & $\begin{array}{r}0.215 \\
23\end{array}$ & $\begin{array}{r}0.21 \\
175\end{array}$ & $\begin{array}{r}0.21 \\
411\end{array}$ & $\begin{array}{r}0.21 \\
270\end{array}$ & $\begin{array}{r}0.21 \\
348\end{array}$ \\
\hline 4 & Data 4 & $\begin{array}{r}0.10 \\
294\end{array}$ & $\begin{array}{r}0.10 \\
230\end{array}$ & $\begin{array}{r}0.10 \\
342\end{array}$ & $\begin{array}{r}0.103 \\
77\end{array}$ & $\begin{array}{r}0.10 \\
166\end{array}$ & $\begin{array}{r}0.10 \\
161\end{array}$ & $\begin{array}{r}0.10 \\
408\end{array}$ & $\begin{array}{r}0.10 \\
417\end{array}$ \\
\hline 5 & Data 5 & $\begin{array}{r}0.10 \\
663\end{array}$ & $\begin{array}{r}0.10 \\
825\end{array}$ & $\begin{array}{r}0.10 \\
802\end{array}$ & $\begin{array}{r}0.112 \\
75\end{array}$ & $\begin{array}{r}0.10 \\
857\end{array}$ & $\begin{array}{r}0.10 \\
844\end{array}$ & $\begin{array}{r}0.10 \\
938\end{array}$ & $\begin{array}{r}0.11 \\
002\end{array}$ \\
\hline 6 & Data 6 & $\begin{array}{c}0.18 \\
350\end{array}$ & $\begin{array}{r}0.18 \\
545\end{array}$ & $\begin{array}{r}0.18 \\
688\end{array}$ & $\begin{array}{r}0.203 \\
68\end{array}$ & $\begin{array}{r}0.19 \\
709\end{array}$ & $\begin{array}{r}0.19 \\
865\end{array}$ & $\begin{array}{r}0.19 \\
945\end{array}$ & $\begin{array}{r}0.20 \\
253\end{array}$ \\
\hline 7 & Data 7 & $\begin{array}{r}0.10 \\
067\end{array}$ & $\begin{array}{r}0.10 \\
090\end{array}$ & $\begin{array}{r}0.10 \\
089\end{array}$ & $\begin{array}{r}0.100 \\
80\end{array}$ & $\begin{array}{r}0.10 \\
086\end{array}$ & $\begin{array}{r}0.10 \\
161\end{array}$ & $\begin{array}{r}0.10 \\
211\end{array}$ & $\begin{array}{r}0.10 \\
241\end{array}$ \\
\hline 8 & Data 8 & $\begin{array}{r}0.17 \\
095\end{array}$ & $\begin{array}{r}0.17 \\
869\end{array}$ & $\begin{array}{r}0.20 \\
759\end{array}$ & $\begin{array}{r}0.190 \\
12\end{array}$ & $\begin{array}{r}0.18 \\
906\end{array}$ & $\begin{array}{r}0.16 \\
633\end{array}$ & $\begin{array}{r}0.16 \\
887\end{array}$ & $\begin{array}{r}0.17 \\
538\end{array}$ \\
\hline 9 & Data 9 & $\begin{array}{r}0.10 \\
089\end{array}$ & $\begin{array}{r}0.10 \\
091\end{array}$ & $\begin{array}{r}0.10 \\
083\end{array}$ & $\begin{array}{r}0.102 \\
05\end{array}$ & $\begin{array}{r}0.10 \\
105\end{array}$ & $\begin{array}{r}0.10 \\
090\end{array}$ & $\begin{array}{r}0.10 \\
144\end{array}$ & $\begin{array}{r}0.10 \\
164\end{array}$ \\
\hline $\begin{array}{l}1 \\
0\end{array}$ & $\begin{array}{l}\text { Data } \\
10\end{array}$ & $\begin{array}{r}0.11 \\
205\end{array}$ & $\begin{array}{r}0.11 \\
239\end{array}$ & $\begin{array}{r}0.10 \\
589\end{array}$ & $\begin{array}{r}0.105 \\
41\end{array}$ & $\begin{array}{r}0.10 \\
501\end{array}$ & $\begin{array}{r}0.10 \\
623\end{array}$ & $\begin{array}{r}0.10 \\
873\end{array}$ & $\begin{array}{r}0.11 \\
221\end{array}$ \\
\hline $\begin{array}{l}1 \\
1\end{array}$ & $\begin{array}{l}\text { Data } \\
11\end{array}$ & $\begin{array}{r}0.28 \\
151\end{array}$ & $\begin{array}{r}0.30 \\
322\end{array}$ & $\begin{array}{r}0.31 \\
083\end{array}$ & $\begin{array}{r}0.330 \\
97\end{array}$ & $\begin{array}{r}0.33 \\
623\end{array}$ & $\begin{array}{r}0.33 \\
421\end{array}$ & $\begin{array}{r}0.34 \\
432\end{array}$ & $\begin{array}{r}0.35 \\
604\end{array}$ \\
\hline $\begin{array}{l}1 \\
2\end{array}$ & $\begin{array}{l}\text { Data } \\
12\end{array}$ & $\begin{array}{r}0.40 \\
700\end{array}$ & $\begin{array}{r}0.41 \\
594\end{array}$ & $\begin{array}{r}0.43 \\
719\end{array}$ & $\begin{array}{r}0.458 \\
77\end{array}$ & $\begin{array}{r}0.43 \\
627\end{array}$ & $\begin{array}{r}0.45 \\
482\end{array}$ & $\begin{array}{r}0.47 \\
697\end{array}$ & $\begin{array}{r}0.46 \\
672\end{array}$ \\
\hline $\begin{array}{l}1 \\
3\end{array}$ & $\begin{array}{l}\text { Data } \\
13\end{array}$ & $\begin{array}{r}0.14 \\
090\end{array}$ & $\begin{array}{r}0.14 \\
573\end{array}$ & $\begin{array}{r}0.14 \\
519\end{array}$ & $\begin{array}{r}0.143 \\
18\end{array}$ & $\begin{array}{r}0.14 \\
640\end{array}$ & $\begin{array}{r}0.14 \\
919\end{array}$ & $\begin{array}{r}0.14 \\
973\end{array}$ & $\begin{array}{r}0.14 \\
988\end{array}$ \\
\hline $\begin{array}{l}1 \\
4\end{array}$ & $\begin{array}{l}\text { Data } \\
14\end{array}$ & $\begin{array}{r}0.46 \\
783\end{array}$ & $\begin{array}{r}0.51 \\
404\end{array}$ & $\begin{array}{r}0.57 \\
528\end{array}$ & $\begin{array}{r}0.615 \\
38\end{array}$ & $\begin{array}{r}0.61 \\
163\end{array}$ & $\begin{array}{r}0.78 \\
489\end{array}$ & $\begin{array}{r}0.88 \\
278\end{array}$ & $\begin{array}{r}0.90 \\
000\end{array}$ \\
\hline $\begin{array}{l}1 \\
5\end{array}$ & $\begin{array}{l}\text { Data } \\
15\end{array}$ & $\begin{array}{r}0.17 \\
290\end{array}$ & $\begin{array}{r}0.20 \\
108\end{array}$ & $\begin{array}{r}0.18 \\
321\end{array}$ & $\begin{array}{r}0.181 \\
98\end{array}$ & $\begin{array}{r}0.17 \\
061\end{array}$ & $\begin{array}{r}0.18 \\
052\end{array}$ & $\begin{array}{r}0.20 \\
252\end{array}$ & $\begin{array}{r}0.20 \\
452\end{array}$ \\
\hline
\end{tabular}




\begin{tabular}{|c|c|c|c|c|c|c|c|c|c|}
\hline $\begin{array}{l}\mathbf{N} \\
\mathbf{o}\end{array}$ & $\begin{array}{l}\text { Nama } \\
\text { Data }\end{array}$ & X1 & X2 & $\mathbf{X 3}$ & $\mathrm{X} 4$ & X5 & X6 & X7 & $\begin{array}{l}\text { Tar } \\
\text { get }\end{array}$ \\
\hline 1 & Data & 0.15 & 0.16 & 0.18 & 0.164 & 0.16 & 0.17 & 0.18 & 0.18 \\
\hline 6 & 16 & 163 & 416 & 412 & 13 & 415 & 185 & 593 & 670 \\
\hline 1 & Data & 0.11 & 0.10 & 0.10 & 0.102 & 0.10 & 0.10 & 0.10 & 0.10 \\
\hline 7 & 17 & 569 & 210 & 222 & 60 & 390 & 619 & 870 & 911 \\
\hline 1 & Data & 0.10 & 0.10 & 0.10 & 0.102 & 0.10 & 0.10 & 0.10 & 0.10 \\
\hline 8 & 18 & 111 & 231 & 192 & 19 & 221 & 223 & 224 & 225 \\
\hline 1 & Data & 0.12 & 0.12 & 0.14 & 0.134 & 0.17 & 0.15 & 0.14 & 0.15 \\
\hline 9 & 19 & 842 & 729 & 186 & 78 & 680 & 581 & 838 & 237 \\
\hline 2 & Data & 0.10 & 0.10 & 0.10 & 0.100 & 0.10 & 0.10 & 0.10 & 0.10 \\
\hline 0 & 20 & 082 & 008 & 024 & 37 & 197 & 234 & 292 & 349 \\
\hline 2 & Data & 0.15 & 0.13 & 0.13 & 0.159 & 0.18 & 0.20 & 0.21 & 0.21 \\
\hline 1 & 21 & 079 & 550 & 667 & 49 & 356 & 571 & 328 & 555 \\
\hline 2 & Data & 0.12 & 0.11 & 0.12 & 0.116 & 0.10 & 0.11 & 0.11 & 0.11 \\
\hline 2 & 22 & 124 & 398 & 137 & 49 & 917 & 296 & 128 & 150 \\
\hline 2 & Data & 0.11 & 0.11 & 0.11 & 0.117 & 0.11 & 0.11 & 0.11 & 0.11 \\
\hline 3 & 23 & 272 & 364 & 489 & 04 & 735 & 823 & 914 & 920 \\
\hline 2 & Data & 0.10 & 0.10 & 0.10 & 0.111 & 0.11 & 0.11 & 0.11 & 0.13 \\
\hline 4 & 24 & 768 & 918 & 799 & 62 & 364 & 285 & 662 & 331 \\
\hline 2 & Data & 0.18 & 0.18 & 0.20 & 0.212 & 0.24 & 0.25 & 0.25 & 0.26 \\
\hline 5 & 25 & 049 & 769 & 550 & 30 & 180 & 676 & 883 & 678 \\
\hline 2 & Data & 0.10 & 0.10 & 0.10 & 0.101 & 0.10 & 0.10 & 0.10 & 0.10 \\
\hline 6 & 26 & 236 & 228 & 185 & 83 & 197 & 255 & 377 & 480 \\
\hline 2 & Data & 0.10 & 0.10 & 0.10 & 0.104 & 0.10 & 0.10 & 0.10 & 0.10 \\
\hline 7 & 27 & 260 & 262 & 365 & 15 & 474 & 484 & 476 & 479 \\
\hline 2 & Data & 0.10 & 0.10 & 0.10 & 0.101 & 0.10 & 0.10 & 0.10 & 0.10 \\
\hline 8 & 28 & 012 & 094 & 099 & 23 & 123 & 182 & 196 & 210 \\
\hline 2 & Data & 0.10 & 0.10 & 0.10 & 0.100 & 0.10 & 0.10 & 0.10 & 0.10 \\
\hline 9 & 29 & 037 & 048 & 053 & 02 & 015 & 000 & 013 & 016 \\
\hline 3 & Data & 0.10 & 0.11 & 0.10 & & 0.10 & 0.10 & 0.10 & 0.10 \\
\hline 0 & 30 & 012 & 891 & 010 & $\begin{array}{r}0.100 \\
44\end{array}$ & 027 & 006 & 015 & 031 \\
\hline 3 & Data & 0.10 & 0.10 & 0.10 & 0.101 & 0.10 & 0.10 & 0.10 & 0.10 \\
\hline 1 & 31 & 047 & 074 & 111 & 25 & 358 & 148 & 155 & 161 \\
\hline 3 & Data & 0.10 & 0.10 & 0.10 & 0.101 & 0.10 & 0.10 & 0.10 & 0.10 \\
\hline 2 & 32 & 119 & 165 & 190 & 51 & 139 & 463 & 729 & 820 \\
\hline
\end{tabular}

Sumber : Badan Pusat Statistik Nasional

\subsection{Perancangan Arsitektur Jaringan Saraf} Tiruan

Jaringan yang digunakan untuk dalam memprediksi Jumlah Produksi Telur Ayam Petelur Berdasarkan Provinsi di Indonesia dengan backpropogation dengan langkah pembelajaran feedforward. Jaringan ini memiliki beberapa lapisan, yaitu lapisan masukan (input), lapisan keluaran (output) dan beberapa lapisan tersembunyi (hidden). Lapisan tersembunyi tersebut membantu jaringan untuk dapat mengenali lebih banyak pola masukan dibandingkan dengan jaringan yang tidak memiliki lapisan tersembunyi. Parameter-parameter dalam pembentukan jaringan backpropagation menggunakan 7 variabel masukan, 1 atau lebih lapisan tersembunyi dan 1 lapisan keluaran. Adapun model arsitektur yang digunakan untuk mendapatkan arsitektur terbaik adalah 4-1, 8-1, 16-1 dan 32-1. Model sampel arsitektur 4-1 dapat dilihat pada gambar dibawah ini:

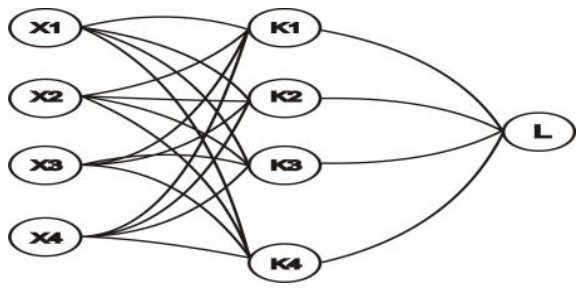

Gambar 1. Arsitektur Jaringan Saraf Tiruan Dalam Memprediksi Jumlah Produksi Telur Ayam Petelur Berdasarkan Provinsi

Jaringan Saraf yang akan dibangun adalah algoritma propagasi balik (backpropagation) dengan fungsi aktivasi Sigmoid. Fungsi aktivasi dalam Jaringan Saraf Tiruan dipakai untuk proses perhitungan terhadap nilai aktual output pada hidden layer dan menghitung nilai aktual output pada output layer.

\subsection{Pendefinisian Output}

Hasil yang diharapkan pada tahap ini adalah deteksi pola menentukan nilai terbaik untuk memprediksi jumlah produksi telur ayam petelur berdasarkan provinsi. Hasil pengujian adalah sebagai berikut :

a. Untuk mengetahui prediksi jumlah telur ayam petelur Berdasarkan Provinsi tentu saja didasarkan pada Data Jumlah produksi telur ayam petelur Berdasarkan Provinsi. Output dari prediksi ini adalah pola arsitektur terbaik dalam memprediksi jumlah produksi telur ayam petelur Berdasarkan Provinsi dengan melihat error minimum.

b. Kategorisasi Output pelatihan (train) dan pengujian (test)

Kategori untuk output ditentukan oleh tingkat error minimum dari target. Batasan kategori tersebut terdapat pada tabel berikut:

Tabel 4. Data Kategorisasi

\begin{tabular}{|c|c|c|}
\hline No & Keterangan & $\begin{array}{c}\text { Error } \\
\text { Minimum }\end{array}$ \\
\hline 1 & Benar & $0.05-0.001$ \\
\hline 2 & Salah & $>0.05$ \\
\hline
\end{tabular}

\subsection{Perancangan arsitektur Jaringan Saraf} Tiruan

Perancangan arsitektur Jaringan Saraf Tiruan untuk data pelatihan dan pengujian, maka digunakan 7 variabel input yaitu:

$$
\begin{aligned}
& X_{1}=\text { Data Tahun 2010 } \\
& X_{2}=\text { Data Tahun 2011 } \\
& X_{3}=\text { Data Tahun 2012 } \\
& X_{4}=\text { Data Tahun 2013 } \\
& X_{5}=\text { Data Tahun 2014 } \\
& X_{6}=\text { Data Tahun 2015 } \\
& X_{7}=\text { Data Tahun 2016 }
\end{aligned}
$$


Berikut tahapan-tahapan yang akan dilakukan dalam pengguna algoritma propagasi balik dengan fungsi aktivasi sigmoid. Tahapan yang harus dilakukan adalah sebagi berikut:

1. Inisialisasi (initialization), merupakan tahap di mana variabel-variabel nilai akan diset atau didefinisikan terlebih dahulu, misalnya seperti: nilai data input, weight, nilai output yang diharapkan, learning rate dan nilai-nilai data lainnya.

2. Aktivasi (activation), merupakan proses perhitungan terhadap nilai aktual output pada hidden layer dan menghitung nilai actual output pada output layer.

3. Weight Training, merupakan proses perhitungan nilai error gradient pada output layer dan menghitung nilai error gradient pada hidden layer

4. Iteration, merupakan tahap akhir dalam penggujian, dimana jika masih terjadi error minimum yang diharapkan belum ditemukan maka kembali pada tahap aktivasi (activation).

\subsubsection{Pelatihan dan Pengujian Arsitektur 7-4-1}

Data Memprediksi Jumlah Produksi Telur Ayam Petelur Berdasarkan Provinsi terdiri dari 32 Data.. Berikut adalah hasil pengujian dengan 32 data pengujian dengan pola pengujian 7-4-1. Data hasil pengujian dan Pelatihan dapat dilihat pada tabel sebagai berikut:

Tabel 5. Hasil Pelatihan dan Pengujian dengan Model 7-4-1

\begin{tabular}{|c|c|c|c|c|c|c|c|c|c|}
\hline \multicolumn{5}{|c|}{ Pelatihan (Train) } & \multicolumn{5}{|c|}{ Pengujian(Test) } \\
\hline $\begin{array}{l}\mathbf{N} \\
\mathbf{0}\end{array}$ & $\begin{array}{l}\text { Tar } \\
\text { get }\end{array}$ & $\begin{array}{c}\text { Outp } \\
\text { ut }\end{array}$ & Error & SSE & $\begin{array}{l}\mathbf{N} \\
\mathbf{o}\end{array}$ & $\begin{array}{c}\text { Targ } \\
\text { et }\end{array}$ & $\begin{array}{c}\text { Outp } \\
\text { ut }\end{array}$ & $\begin{array}{c}\text { Erro } \\
\mathbf{r}\end{array}$ & SSE \\
\hline 1 & $\begin{array}{r}0.10 \\
528\end{array}$ & $\begin{array}{r}0.084 \\
4479\end{array}$ & $\begin{array}{r}.021 \\
9521\end{array}$ & $\begin{array}{r}0.000 \\
4819\end{array}$ & 1 & $\begin{array}{r}0.106 \\
395\end{array}$ & $\begin{array}{r}0.084 \\
4744\end{array}$ & $\begin{array}{r}0.022 \\
376\end{array}$ & $\begin{array}{r}0.000 \\
501\end{array}$ \\
\hline 2 & $\begin{array}{r}0.33 \\
917\end{array}$ & $\begin{array}{r}0.137 \\
9801\end{array}$ & $\begin{array}{r}0.210 \\
3699\end{array}$ & $\begin{array}{r}0.044 \\
2555\end{array}$ & 2 & $\begin{array}{r}0.348 \\
347\end{array}$ & $\begin{array}{r}0.091 \\
391\end{array}$ & $\begin{array}{r}0.258 \\
069\end{array}$ & $\begin{array}{r}0.066 \\
6\end{array}$ \\
\hline 3 & $\begin{array}{r}0.21 \\
411\end{array}$ & $\begin{array}{r}0.060 \\
3317\end{array}$ & $\begin{array}{r}0.152 \\
3683\end{array}$ & $\begin{array}{r}0.023 \\
2161\end{array}$ & 3 & $\begin{array}{r}0.212 \\
703\end{array}$ & $\begin{array}{r}0.056 \\
7361\end{array}$ & $\begin{array}{r}0.156 \\
744\end{array}$ & $\begin{array}{r}0.024 \\
569\end{array}$ \\
\hline 4 & $\begin{array}{r}0.10 \\
161\end{array}$ & $\begin{array}{r}0.085 \\
2535\end{array}$ & $\begin{array}{r}0.018 \\
8265\end{array}$ & $\begin{array}{r}0.000 \\
3544\end{array}$ & 4 & $\begin{array}{r}0.104 \\
082\end{array}$ & $\begin{array}{r}0.084 \\
3621\end{array}$ & $\begin{array}{r}0.019 \\
808\end{array}$ & $\begin{array}{r}0.000 \\
392\end{array}$ \\
\hline 5 & $\begin{array}{r}0.10 \\
844\end{array}$ & $\begin{array}{r}0.086 \\
3183\end{array}$ & $\begin{array}{r}0.023 \\
0617\end{array}$ & $\begin{array}{r}0.000 \\
5318\end{array}$ & 5 & $\begin{array}{r}0.109 \\
382\end{array}$ & $\begin{array}{r}0.083 \\
2006\end{array}$ & $\begin{array}{r}0.026 \\
819\end{array}$ & $\begin{array}{r}0.000 \\
719\end{array}$ \\
\hline 6 & $\begin{array}{r}0.19 \\
865\end{array}$ & $\begin{array}{r}0.068 \\
6095\end{array}$ & $\begin{array}{r}0.130 \\
8405\end{array}$ & $\begin{array}{r}0.017 \\
1192\end{array}$ & 6 & $\begin{array}{r}0.199 \\
452\end{array}$ & $\begin{array}{r}0.063 \\
6328\end{array}$ & $\begin{array}{r}0.138 \\
897\end{array}$ & $\begin{array}{r}0.019 \\
292\end{array}$ \\
\hline 7 & $\begin{array}{r}0.10 \\
161\end{array}$ & $\begin{array}{r}0.086 \\
0255\end{array}$ & $\begin{array}{r}0.016 \\
0845\end{array}$ & $\begin{array}{r}0.000 \\
2587\end{array}$ & 7 & $\begin{array}{r}0.102 \\
109\end{array}$ & $\begin{array}{r}0.086 \\
3057\end{array}$ & $\begin{array}{r}0.016 \\
104\end{array}$ & $\begin{array}{r}0.000 \\
259\end{array}$ \\
\hline 8 & $\begin{array}{r}0.16 \\
633\end{array}$ & $\begin{array}{r}0.068 \\
2171\end{array}$ & $\begin{array}{r}0.100 \\
6529\end{array}$ & $\begin{array}{r}0.010 \\
131\end{array}$ & 8 & $\begin{array}{r}0.168 \\
868\end{array}$ & $\begin{array}{r}0.051 \\
6918\end{array}$ & $\begin{array}{r}0.123 \\
688\end{array}$ & $\begin{array}{r}0.015 \\
299\end{array}$ \\
\hline 9 & $\begin{array}{r}0.10 \\
090\end{array}$ & $\begin{array}{r}0.086 \\
4033\end{array}$ & $\begin{array}{r}0.015 \\
0367\end{array}$ & $\begin{array}{r}0.000 \\
2261\end{array}$ & 9 & $\begin{array}{r}0.101 \\
438\end{array}$ & $\begin{array}{r}0.085 \\
7627\end{array}$ & $\begin{array}{r}0.015 \\
877\end{array}$ & $\begin{array}{r}0.000 \\
252\end{array}$ \\
\hline $\begin{array}{l}1 \\
0\end{array}$ & $\begin{array}{r}0.10 \\
623\end{array}$ & $\begin{array}{r}0.079 \\
1459\end{array}$ & $\begin{array}{r}0.029 \\
5841\end{array}$ & $\begin{array}{r}0.000 \\
8752\end{array}$ & $\begin{array}{l}1 \\
0\end{array}$ & $\begin{array}{r}0.108 \\
728\end{array}$ & $\begin{array}{c}0.082 \\
3066\end{array}$ & $\begin{array}{r}0.029 \\
903\end{array}$ & $\begin{array}{r}0.000 \\
894\end{array}$ \\
\hline $\begin{array}{l}1 \\
1\end{array}$ & $\begin{array}{r}0.33 \\
421\end{array}$ & $\begin{array}{r}0.077 \\
9315\end{array}$ & $\begin{array}{r}0.266 \\
3885\end{array}$ & $\begin{array}{r}0.070 \\
9628\end{array}$ & $\begin{array}{l}1 \\
1\end{array}$ & $\begin{array}{r}0.344 \\
324\end{array}$ & $\begin{array}{r}0.078 \\
7617\end{array}$ & $\begin{array}{r}0.277 \\
278\end{array}$ & $\begin{array}{r}0.076 \\
883\end{array}$ \\
\hline $\begin{array}{l}1 \\
2\end{array}$ & $\begin{array}{r}0.45 \\
482\end{array}$ & $\begin{array}{r}0.262 \\
1673\end{array}$ & $\begin{array}{r}0.214 \\
8027\end{array}$ & $\begin{array}{r}0.046 \\
1402\end{array}$ & $\begin{array}{l}1 \\
2\end{array}$ & $\begin{array}{r}0.476 \\
974\end{array}$ & $\begin{array}{r}0.274 \\
6527\end{array}$ & $\begin{array}{r}0.192 \\
067\end{array}$ & $\begin{array}{r}0.036 \\
89\end{array}$ \\
\hline $\begin{array}{l}1 \\
3\end{array}$ & $\begin{array}{r}0.14 \\
919\end{array}$ & $\begin{array}{r}0.073 \\
5148\end{array}$ & $\begin{array}{r}0.076 \\
2152\end{array}$ & $\begin{array}{r}0.005 \\
8088\end{array}$ & $\begin{array}{l}1 \\
3\end{array}$ & $\begin{array}{r}0.149 \\
731\end{array}$ & $\begin{array}{r}0.074 \\
543\end{array}$ & $\begin{array}{r}0.075 \\
337\end{array}$ & $\begin{array}{r}0.005 \\
676\end{array}$ \\
\hline $\begin{array}{l}1 \\
4\end{array}$ & $\begin{array}{r}0.78 \\
489\end{array}$ & $\begin{array}{r}0.791 \\
3159\end{array}$ & $\begin{array}{r}0.091 \\
4641\end{array}$ & $\begin{array}{r}0.008 \\
3657\end{array}$ & $\begin{array}{l}1 \\
4\end{array}$ & $\begin{array}{r}0.882 \\
776\end{array}$ & $\begin{array}{r}0.887 \\
3654\end{array}$ & $\begin{array}{r}0.012 \\
635\end{array}$ & $\begin{array}{r}0.000 \\
16\end{array}$ \\
\hline $\begin{array}{l}1 \\
5\end{array}$ & $\begin{array}{r}0.18 \\
052\end{array}$ & $\begin{array}{r}0.053 \\
9763\end{array}$ & $\begin{array}{r}0.148 \\
5437\end{array}$ & $\begin{array}{r}0.022 \\
0652\end{array}$ & $\begin{array}{l}1 \\
5\end{array}$ & $\begin{array}{r}0.202 \\
519\end{array}$ & $\begin{array}{r}0.052 \\
7768\end{array}$ & $\begin{array}{r}0.151 \\
743\end{array}$ & $\begin{array}{r}0.023 \\
026\end{array}$ \\
\hline $\begin{array}{l}1 \\
6\end{array}$ & $\begin{array}{r}0.17 \\
185\end{array}$ & 0.066 & $\begin{array}{r}0.119 \\
5779\end{array}$ & $\begin{array}{r}0.014 \\
2989\end{array}$ & 1 & $\begin{array}{r}0.185 \\
935\end{array}$ & $\begin{array}{r}0.060 \\
0034\end{array}$ & $\begin{array}{r}0.126 \\
697\end{array}$ & $\begin{array}{r}0.016 \\
052\end{array}$ \\
\hline
\end{tabular}

\begin{tabular}{|c|c|c|c|c|c|c|c|c|c|}
\hline \multicolumn{5}{|c|}{ Pelatihan (Train) } & \multicolumn{5}{|c|}{ Pengujian(Test) } \\
\hline $\begin{array}{l}\mathbf{N} \\
\mathbf{0}\end{array}$ & $\begin{array}{l}\text { Tar } \\
\text { get }\end{array}$ & $\begin{array}{c}\text { Outp } \\
\text { ut }\end{array}$ & Error & SSE & $\begin{array}{l}\mathbf{N} \\
\mathbf{0}\end{array}$ & $\begin{array}{c}\text { Targ } \\
\text { et }\end{array}$ & $\begin{array}{c}\text { Outp } \\
\text { ut }\end{array}$ & $\begin{array}{c}\text { Erro } \\
\mathbf{r}\end{array}$ & SSE \\
\hline 1 & 0.10 & 0.081 & 0.026 & 0.000 & 1 & 0.108 & 0.088 & 0.020 & 0.000 \\
\hline 7 & 619 & 7338 & 9662 & 7272 & 7 & 699 & 1673 & 943 & 439 \\
\hline 1 & 0.10 & 0.086 & 0.016 & 0.000 & 1 & 0.102 & 0.085 & 0.016 & 0.000 \\
\hline 8 & 223 & 0151 & 2249 & 2632 & 8 & 237 & 6744 & 576 & 275 \\
\hline 1 & 0.15 & 0.096 & 0.052 & 0.002 & 1 & 0.148 & 0.100 & 0.051 & 0.002 \\
\hline 9 & 581 & 1516 & 2284 & 7278 & 9 & 381 & 6855 & 684 & 671 \\
\hline 2 & 0.10 & 0.086 & 0.016 & 0.000 & 2 & 0.102 & 0.087 & 0.015 & 0.000 \\
\hline 0 & 234 & 8206 & 0994 & 2592 & 0 & 922 & 7799 & 71 & 247 \\
\hline 2 & 0.20 & 0.096 & 0.116 & 0.013 & 2 & 0.213 & 0.120 & 0.095 & 0.009 \\
\hline 1 & 571 & 9873 & 2927 & 524 & 1 & 279 & 3462 & 204 & 064 \\
\hline 2 & 0.11 & 0.077 & 0.033 & 0.001 & 2 & 0.111 & 0.076 & 0.034 & 0.001 \\
\hline 2 & 296 & 474 & 806 & 1428 & 2 & 277 & 5611 & 939 & 221 \\
\hline 2 & 0.11 & 0.085 & 0.033 & 0.001 & 2 & 0.119 & 0.084 & 0.034 & 0.001 \\
\hline 3 & 823 & 2311 & 9089 & 1498 & 3 & 136 & 2571 & 943 & 221 \\
\hline 2 & 0.11 & 0.087 & 0.029 & 0.000 & 2 & 0.116 & 0.087 & 0.046 & 0.002 \\
\hline 4 & 285 & 2955 & 3245 & 8599 & 4 & 624 & 0484 & 262 & 14 \\
\hline 2 & 0.25 & 0.080 & 0.178 & 0.031 & 2 & 0.258 & 0.085 & 0.181 & 0.033 \\
\hline 5 & 676 & 5869 & 2431 & 7706 & 5 & 834 & 0528 & 727 & 025 \\
\hline 2 & 0.10 & 0.085 & 0.018 & 0.000 & 2 & 0.103 & 0.085 & 0.018 & 0.000 \\
\hline 6 & 255 & 3765 & 3935 & 3383 & 6 & 768 & 9688 & 831 & 355 \\
\hline 2 & 0.10 & 0.086 & 0.018 & 0.000 & 2 & 0.104 & 0.086 & 0.018 & 0.000 \\
\hline 7 & 484 & 7228 & 0372 & 3253 & 7 & 764 & 3661 & 424 & 339 \\
\hline 2 & 0.10 & 0.086 & 0.015 & 0.000 & 2 & 0.101 & 0.086 & 0.015 & 0.000 \\
\hline 8 & 182 & 5053 & 4547 & 2388 & 8 & 96 & 3337 & 766 & 249 \\
\hline 2 & 0.10 & 0.085 & 0.014 & 0.000 & 2 & 0.100 & 0.085 & 0.014 & 0.000 \\
\hline 9 & 000 & 7384 & 3916 & 2071 & 9 & 128 & 8032 & 357 & 206 \\
\hline 3 & 0.10 & 0.078 & 0.021 & 0.000 & 3 & 0.100 & 0.079 & 0.020 & 0.000 \\
\hline 0 & 006 & 5156 & 6344 & 468 & 0 & 15 & 5084 & 802 & 433 \\
\hline 3 & 0.10 & 0.087 & 0.014 & 0.000 & 3 & 0.101 & 0.087 & 0.014 & 0.000 \\
\hline 1 & 148 & 2828 & 2672 & 2036 & 1 & 552 & 0325 & 577 & 213 \\
\hline 3 & 0.10 & 0.085 & 0.021 & 0.000 & 3 & 0.107 & 0.087 & 0.021 & 0.000 \\
\hline \multirow[t]{4}{*}{2} & 463 & 9486 & 3414 & 4555 & 2 & 285 & 1456 & 054 & 443 \\
\hline & & & & & \multicolumn{4}{|c|}{ Total } & $\begin{array}{r}0.340 \\
003\end{array}$ \\
\hline & & & & & \multicolumn{4}{|c|}{ MSE } & $\begin{array}{r}0.010 \\
625\end{array}$ \\
\hline & & & & & \multicolumn{4}{|c|}{ Akurasi Kebenaran \% } & 96.88 \\
\hline
\end{tabular}

\subsubsection{Pelatihan dan Pengujian Arsitektur 7-8-1}

Berikut adalah hasil pengujian dengan 7-8-1 data pengujian dengan pola pengujian 8-1. Data hasil pengujian dan Pelatihan dapat dilihat pada tabel sebagai berikut:

Tabel 6. Hasil Pelatihan dan Pengujian dengan Model

\begin{tabular}{|c|c|c|c|c|c|c|c|c|c|}
\hline \multicolumn{5}{|c|}{ Pelatihan(Train) } & \multicolumn{5}{|c|}{ Pengujian(Test) } \\
\hline $\begin{array}{l}\mathbf{N} \\
\mathbf{o}\end{array}$ & $\begin{array}{c}\text { Ta } \\
\text { rge } \\
\text { t }\end{array}$ & $\begin{array}{l}\text { Out } \\
\text { put }\end{array}$ & $\begin{array}{c}\text { Erro } \\
\mathbf{r}\end{array}$ & SSE & $\begin{array}{l}\mathbf{N} \\
\mathbf{0}\end{array}$ & $\begin{array}{l}\text { Tar } \\
\text { get }\end{array}$ & $\begin{array}{l}\text { Out } \\
\text { put }\end{array}$ & $\begin{array}{c}\text { Erro } \\
\mathbf{r}\end{array}$ & SSE \\
\hline \multirow[t]{3}{*}{1} & 0.1 & 0.08 & 0.025 & 0.00 & 1 & 0.10 & 0.08 & 0.025 & 0.00 \\
\hline & 052 & 0624 & 7751 & 0664 & & 639 & 0852 & 9975 & 0675 \\
\hline & 8 & 9 & & 4 & & 5 & 5 & & \\
\hline \multirow[t]{3}{*}{2} & 0.3 & 0.31 & 0.033 & 0.00 & 2 & 0.34 & 0.44 & - & 0.00 \\
\hline & 391 & 5271 & 0783 & 1094 & & 834 & 1277 & 0.091 & 8430 \\
\hline & 7 & 7 & & 2 & & 7 & 5 & 8175 & 5 \\
\hline \multirow[t]{3}{*}{3} & 0.2 & 0.11 & 0.096 & 0.00 & 3 & 0.21 & 0.12 & 0.091 & 0.00 \\
\hline & 141 & 6011 & 6882 & 9348 & & 270 & 2354 & 1253 & 8303 \\
\hline & 1 & 8 & & 6 & & 3 & 7 & & \\
\hline \multirow[t]{3}{*}{4} & 0.1 & 0.08 & 0.023 & 0.00 & 4 & 0.10 & 0.08 & 0.023 & 0.00 \\
\hline & 016 & 0585 & 4942 & 0552 & & 408 & 0572 & 5977 & 0556 \\
\hline & 1 & 8 & & & & 2 & 3 & & 9 \\
\hline \multirow[t]{3}{*}{5} & 0.1 & 0.08 & 0.028 & 0.00 & 5 & 0.10 & 0.08 & 0.029 & 0.00 \\
\hline & 084 & 0981 & 3988 & 0806 & & 938 & 1012 & 0079 & 0841 \\
\hline & 4 & 2 & & 5 & & 2 & 1 & & 5 \\
\hline \multirow[t]{3}{*}{6} & 0.1 & 0.10 & 0.097 & 0.00 & 6 & 0.19 & 0.10 & 0.098 & 0.00 \\
\hline & 986 & 1905 & 5441 & 9514 & & 945 & 4009 & 5209 & 9706 \\
\hline & 5 & 9 & & 9 & & 2 & 1 & & 4 \\
\hline \multirow[t]{3}{*}{7} & 0.1 & 0.08 & 0.021 & 0.00 & 7 & 0.10 & 0.08 & 0.021 & 0.00 \\
\hline & 016 & 0458 & 6517 & 0468 & & 210 & 0484 & 9256 & 0480 \\
\hline & 1 & 3 & & 8 & & 9 & 4 & & 7 \\
\hline \multirow[t]{3}{*}{8} & 0.1 & 0.09 & 0.069 & 0.00 & 8 & 0.16 & 0.10 & 0.072 & 0.00 \\
\hline & 663 & 9693 & 1768 & 4785 & & 886 & 3009 & 371 & 5237 \\
\hline & 3 & 2 & & 4 & & 8 & & & 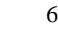 \\
\hline
\end{tabular}




\begin{tabular}{|c|c|c|c|c|c|c|c|c|c|}
\hline \multicolumn{5}{|c|}{ Pelatihan(Train) } & \multicolumn{5}{|c|}{ Pengujian(Test) } \\
\hline $\begin{array}{l}\mathbf{N} \\
\mathbf{o}\end{array}$ & $\begin{array}{c}\text { Ta } \\
\text { rge } \\
\text { t }\end{array}$ & $\begin{array}{l}\text { Out } \\
\text { put }\end{array}$ & $\begin{array}{c}\text { Erro } \\
\mathbf{r}\end{array}$ & SSE & $\begin{array}{l}\mathbf{N} \\
\mathbf{0}\end{array}$ & $\begin{array}{l}\text { Tar } \\
\text { get }\end{array}$ & $\begin{array}{l}\text { Out } \\
\text { put }\end{array}$ & $\begin{array}{c}\text { Erro } \\
\mathbf{r}\end{array}$ & SSE \\
\hline \multirow[t]{3}{*}{9} & 0.1 & 0.08 & 0.020 & 0.00 & 9 & 0.10 & 0.08 & 0.021 & 0.00 \\
\hline & 009 & 0475 & 9642 & 0439 & & 143 & 0452 & 188 & 0448 \\
\hline & 0 & 8 & & 5 & & 8 & & & 9 \\
\hline 1 & 0.1 & 0.08 & 0.027 & 0.00 & 1 & 0.10 & 0.08 & 0.030 & 0.00 \\
\hline \multirow[t]{2}{*}{0} & 062 & 1516 & 2139 & 0740 & 0 & 872 & 1212 & 9976 & 0960 \\
\hline & 3 & 1 & & 6 & & 8 & 4 & & 9 \\
\hline 1 & 0.3 & 0.54 & - & 0.04 & 1 & 0.34 & 0.63 & - & 0.07 \\
\hline \multirow[t]{2}{*}{1} & 342 & 4670 & 0.200 & 0140 & 1 & 432 & 4636 & 0.278 & 7616 \\
\hline & 1 & 1 & 3501 & 2 & & 4 & 9 & 5969 & 2 \\
\hline 1 & 0.4 & 0.85 & - & 0.14 & 1 & 0.47 & 0.85 & - & 0.14 \\
\hline 2 & 548 & 7373 & 0.380 & 4707 & 2 & 697 & 2897 & 0.386 & 9133 \\
\hline & 2 & 7 & 4037 & & & 4 & 6 & 1776 & 1 \\
\hline 1 & 0.1 & 0.08 & 0.063 & 0.00 & 1 & 0.14 & 0.08 & 0.063 & 0.00 \\
\hline 3 & 491 & 5814 & 9157 & 4085 & 3 & 973 & 6408 & 4712 & 4028 \\
\hline & 9 & 3 & & 2 & & 1 & 8 & & 6 \\
\hline 1 & 0.7 & 0.70 & 0.174 & 0.03 & 1 & 0.88 & 0.78 & 0.113 & 0.01 \\
\hline 4 & 848 & 8763 & 0168 & 0281 & 4 & 277 & 6696 & 3038 & 2837 \\
\hline & 9 & 2 & & 8 & & 6 & 2 & & 7 \\
\hline 1 & 0.1 & 0.09 & 0.103 & 0.01 & 1 & 0.20 & 0.10 & 0.102 & 0.01 \\
\hline 5 & 805 & 9174 & 3453 & 0680 & 5 & 251 & 1937 & 5823 & 0523 \\
\hline & 2 & 7 & & 2 & & 9 & 7 & & 1 \\
\hline 1 & 0.1 & 0.08 & 0.096 & 0.00 & 1 & 0.18 & 0.09 & 0.093 & 0.00 \\
\hline 6 & 718 & 9460 & 4698 & 9306 & 6 & 593 & 3521 & 1786 & 8682 \\
\hline & 5 & 2 & & 4 & & 5 & 4 & & 2 \\
\hline 1 & 0.1 & 0.08 & 0.027 & 0.00 & 1 & 0.10 & 0.08 & 0.028 & 0.00 \\
\hline 7 & 061 & 1258 & 4419 & 0753 & 7 & 869 & 0564 & 5456 & 0814 \\
\hline & 9 & 1 & & 1 & & 9 & 4 & & 9 \\
\hline 1 & 0.1 & 0.08 & 0.021 & 0.00 & 1 & 0.10 & 0.08 & 0.021 & 0.00 \\
\hline 8 & 022 & 0542 & 698 & 0470 & 8 & 223 & 0579 & 6702 & 0469 \\
\hline & 3 & & & 8 & & 7 & 8 & & 6 \\
\hline 1 & 0.1 & 0.08 & 0.063 & 0.00 & 1 & 0.14 & 0.08 & 0.067 & 0.00 \\
\hline 9 & 558 & 4806 & 5733 & 4041 & 9 & 838 & 4697 & 6721 & 4579 \\
\hline & 1 & 7 & & 6 & & 1 & 9 & & 5 \\
\hline 2 & 0.1 & 0.08 & 0.022 & 0.00 & 2 & 0.10 & 0.08 & 0.023 & 0.00 \\
\hline 0 & 023 & 0467 & 453 & 0504 & 0 & 292 & 0419 & 0701 & 0532 \\
\hline & 4 & & & 1 & & 2 & 9 & & 2 \\
\hline 2 & 0.2 & 0.08 & 0.127 & 0.01 & 2 & 0.21 & 0.08 & 0.129 & 0.01 \\
\hline 1 & 057 & 6231 & 0486 & 6141 & 1 & 327 & 5912 & 6377 & 6805 \\
\hline & 1 & 4 & & 3 & & 9 & 3 & & 9 \\
\hline 2 & 0.1 & 0.08 & 0.029 & 0.00 & 2 & 0.11 & 0.08 & 0.029 & 0.00 \\
\hline 2 & 129 & 1806 & 4734 & 0868 & 2 & 127 & 2106 & 3935 & 0864 \\
\hline & 6 & 6 & & 7 & & 7 & 5 & & \\
\hline 2 & 0.1 & 0.08 & 0.037 & 0.00 & 2 & 0.11 & 0.08 & 0.037 & 0.00 \\
\hline 3 & 182 & 1556 & 5839 & 1412 & 3 & 913 & 1656 & 5433 & 1409 \\
\hline & 3 & 1 & & 5 & & 6 & 7 & & 5 \\
\hline 2 & 0.1 & 0.08 & 0.035 & 0.00 & 2 & 0.11 & 0.08 & 0.052 & 0.00 \\
\hline 4 & 128 & 1183 & 4368 & 1255 & 4 & 662 & 1028 & 2818 & 2733 \\
\hline & 5 & 2 & & 8 & & 4 & 2 & & 4 \\
\hline 2 & 0.2 & 0.10 & 0.152 & 0.02 & 2 & 0.25 & 0.11 & 0.146 & 0.02 \\
\hline 5 & 567 & 5918 & 9113 & 3381 & 5 & 883 & 9904 & 8752 & 1572 \\
\hline & 6 & 7 & & 9 & & 4 & 8 & & 3 \\
\hline 2 & 0.1 & 0.08 & 0.023 & 0.00 & 2 & 0.10 & 0.08 & 0.024 & 0.00 \\
\hline 6 & 025 & 0592 & 1774 & 0537 & 6 & 376 & 0564 & 2357 & 0587 \\
\hline & 5 & 6 & & 2 & & 8 & 3 & & 4 \\
\hline 2 & 0.1 & 0.08 & 0.024 & 0.00 & 2 & 0.10 & 0.08 & 0.024 & 0.00 \\
\hline 7 & 048 & 0615 & 1448 & 0583 & 7 & 476 & 0652 & 1371 & 0582 \\
\hline & 4 & 2 & & & & 4 & 9 & & 6 \\
\hline 2 & 0.1 & 0.08 & 0.021 & 0.00 & 2 & 0.10 & 0.08 & 0.021 & 0.00 \\
\hline 8 & 018 & 0435 & 5243 & 0463 & 8 & 196 & 049 & 61 & 0467 \\
\hline & 2 & 7 & & 3 & & & & & \\
\hline 2 & 0.1 & 0.08 & 0.019 & 0.00 & 2 & 0.10 & 0.08 & 0.019 & 0.00 \\
\hline 9 & 000 & 0447 & 6826 & 0387 & 9 & 012 & 0453 & 7066 & 0388 \\
\hline & 0 & 4 & & 4 & & 8 & 4 & & 3 \\
\hline 3 & 0.1 & 0.08 & 0.018 & 0.00 & 3 & 0.10 & 0.08 & 0.018 & 0.00 \\
\hline 0 & 000 & 1297 & 8525 & 0355 & 0 & 015 & 1385 & 9241 & 0358 \\
\hline & 6 & 5 & & 4 & & & 9 & & 1 \\
\hline 3 & 0.1 & 0.08 & 0.021 & 0.00 & 3 & 0.10 & 0.08 & 0.021 & 0.00 \\
\hline 1 & 014 & 0524 & 0252 & 0442 & 1 & 155 & 0456 & 1539 & 0447 \\
\hline & 8 & 8 & & 1 & & 2 & 1 & & 5 \\
\hline 3 & 0.1 & 0.08 & 0.026 & 0.00 & 3 & 0.10 & 0.08 & 0.027 & 0.00 \\
\hline 2 & 046 & 0453 & 837 & 0720 & 2 & 728 & 0548 & 652 & 0764 \\
\hline & 3 & & & 2 & & 5 & & & 6 \\
\hline & & & & & & & TAL & & 0.35 \\
\hline & & & & & & & & & 1840 \\
\hline & & & & & & & & & \\
\hline & & & & & & & ISE & & 0.01 \\
\hline
\end{tabular}

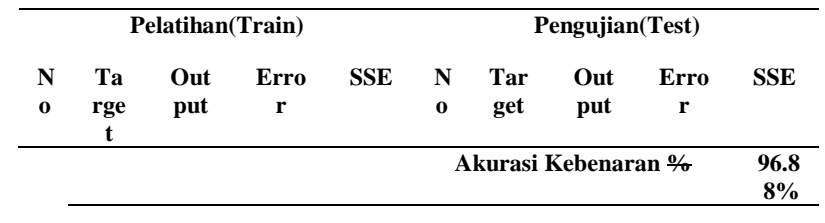

\subsubsection{Pelatihan dan Pengujian Arsitektur 7-16-1}

Berikut adalah hasil pengujian dengan 7-16-1 data pengujian dengan pola pengujian 16-1. Data hasil pengujian dan Pelatihan dapat dilihat pada tabel sebagai berikut:

Tabel 7. Hasil Pelatihan dan Pengujian dengan Model 16-1

\begin{tabular}{|c|c|c|c|c|c|c|c|c|c|}
\hline \multicolumn{5}{|c|}{ Pelatihan (Train) } & \multicolumn{5}{|c|}{ Pengujian (Test) } \\
\hline $\begin{array}{l}\mathbf{N} \\
\mathbf{o}\end{array}$ & $\begin{array}{c}\text { Ta } \\
\text { rge } \\
\text { t }\end{array}$ & $\begin{array}{l}\text { Out } \\
\text { put }\end{array}$ & $\begin{array}{c}\text { Erro } \\
\mathbf{r}\end{array}$ & SSE & $\begin{array}{l}\mathbf{N} \\
\mathbf{o}\end{array}$ & $\begin{array}{l}\text { Tar } \\
\text { get }\end{array}$ & $\begin{array}{l}\text { Out } \\
\text { put }\end{array}$ & $\begin{array}{c}\text { Erro } \\
\mathbf{r}\end{array}$ & SSE \\
\hline \multirow[t]{3}{*}{1} & 0.1 & 0.17 & - & 0.00 & 1 & 0.10 & 0.17 & - & 0.00 \\
\hline & 052 & 2409 & 0.06 & 4357 & & 6395 & 6499 & 0.06 & 4851 \\
\hline & 8 & 7 & $\begin{array}{c}6009 \\
7\end{array}$ & 3 & & 5 & 9 & $\begin{array}{c}9649 \\
9\end{array}$ & 1 \\
\hline \multirow[t]{3}{*}{2} & 0.3 & 0.29 & 0.04 & 0.00 & 2 & 0.34 & 0.29 & 0.05 & 0.00 \\
\hline & 391 & 9104 & 9245 & 2425 & & 8347 & 6304 & 3155 & 2825 \\
\hline & 7 & 1 & 9 & 2 & & 5 & 3 & 7 & 5 \\
\hline \multirow[t]{4}{*}{3} & 0.2 & 0.36 & - & 0.02 & 3 & 0.21 & 0.39 & - & 0.03 \\
\hline & 141 & 9889 & 0.15 & 4708 & & 2703 & 5941 & 0.18 & 3292 \\
\hline & 1 & 6 & 7189 & 6 & & 2 & 3 & 2461 & 1 \\
\hline & & & 6 & & & & & 3 & \\
\hline \multirow[t]{4}{*}{4} & 0.1 & 0.17 & - & 0.00 & 4 & 0.10 & 0.17 & - & 0.00 \\
\hline & 016 & 1103 & 0.06 & 4492 & & 4081 & 3416 & 0.06 & 4795 \\
\hline & 1 & 4 & 7023 & 1 & & 5 & 5 & 9246 & 1 \\
\hline & & & 4 & & & & & 5 & \\
\hline \multirow[t]{4}{*}{5} & 0.1 & 0.17 & - & 0.00 & 5 & 0.10 & 0.17 & - & 0.00 \\
\hline & 084 & 2960 & 0.06 & 4042 & & 9382 & 5002 & 0.06 & 4222 \\
\hline & 4 & 4 & 3580 & 5 & & 2 & 9 & 4982 & 8 \\
\hline & & & 4 & & & & & 9 & \\
\hline \multirow[t]{4}{*}{6} & 0.1 & 0.32 & - & 0.01 & 6 & 0.19 & 0.31 & - & 0.01 \\
\hline & 986 & 3189 & 0.12 & 5311 & & 9452 & 6688 & 0.11 & 3032 \\
\hline & 5 & 3 & 3739 & 4 & & & & 4158 & \\
\hline & & & 3 & & & & & & \\
\hline \multirow[t]{4}{*}{7} & 0.1 & 0.17 & - & 0.00 & 7 & 0.10 & 0.17 & - & 0.00 \\
\hline & 016 & 0431 & 0.06 & 4667 & & 2108 & 06 & 0.06 & 4649 \\
\hline & 1 & 2 & 8321 & 8 & & 8 & & 819 & 9 \\
\hline & & & 2 & & & & & & \\
\hline \multirow[t]{4}{*}{8} & 0.1 & 0.22 & - & 0.00 & 8 & 0.16 & 0.34 & - & 0.03 \\
\hline & 663 & 6366 & 0.05 & 3305 & & 8868 & 9815 & 0.17 & 0427 \\
\hline & 3 & 8 & 7496 & 9 & & 1 & 8 & 4435 & 9 \\
\hline & & & 8 & & & & & 8 & \\
\hline \multirow[t]{4}{*}{9} & 0.1 & 0.16 & - & 0.00 & 9 & 0.10 & 0.16 & - & 0.00 \\
\hline & 009 & 9609 & 0.06 & 4647 & & 1437 & 9699 & 0.06 & 4632 \\
\hline & 0 & 3 & 8169 & 1 & & 5 & 9 & 8059 & 1 \\
\hline & & & 3 & & & & & 9 & \\
\hline 1 & 0.1 & 0.19 & - & 0.00 & 1 & 0.10 & 0.18 & - & 0.00 \\
\hline \multirow[t]{3}{*}{0} & 062 & 2140 & 0.08 & 6957 & 0 & 8727 & 8982 & 0.07 & 5893 \\
\hline & 3 & 5 & 3410 & 3 & & 9 & & 6772 & 9 \\
\hline & & & 5 & & & & & & \\
\hline 1 & 0.3 & & - & 0.00 & 1 & 0.3 & 0.39 & - & 0.00 \\
\hline \multirow[t]{3}{*}{1} & 342 & 8349 & 0.04 & 1938 & 1 & 4324 & 5775 & 0.03 & 1578 \\
\hline & 1 & 6 & 4029 & 6 & & 3 & 1 & 9735 & 9 \\
\hline & & & 6 & & & & & 1 & \\
\hline 1 & 0.4 & 0.30 & 0.17 & 0.03 & 1 & 0.47 & 0.27 & 0.18 & 0.03 \\
\hline \multirow[t]{2}{*}{2} & 548 & 1368 & 5601 & 0836 & 2 & 6974 & 9429 & 7290 & 5077 \\
\hline & 2 & 1 & 9 & & & 2 & 1 & 9 & 9 \\
\hline 1 & 0.1 & 0.23 & - & 0.00 & 1 & 0.14 & 0.23 & - & 0.00 \\
\hline \multirow[t]{3}{*}{3} & 491 & 1352 & 0.08 & 6662 & 3 & 9730 & 9883 & 0.09 & 8100 \\
\hline & 9 & 1 & 1622 & 2 & & 5 & 3 & 0003 & 6 \\
\hline & & & 1 & & & & & 3 & \\
\hline 1 & 0.7 & 0.55 & 0.33 & 0.1 & 1 & 0.88 & 0.6 & 0.26 & 0.07 \\
\hline \multirow[t]{2}{*}{4} & 848 & 1874 & 0905 & 9498 & 4 & 2776 & 4009 & 5990 & 0751 \\
\hline & 9 & 6 & 4 & 4 & & 1 & 3 & 7 & 1 \\
\hline 1 & 0.1 & 0.34 & - & 0.02 & 1 & 0.20 & 0.44 & - & 0.05 \\
\hline 5 & 805 & 8275 & 0.14 & 1244 & 5 & 2518 & 8020 & 0.24 & 9292 \\
\hline
\end{tabular}




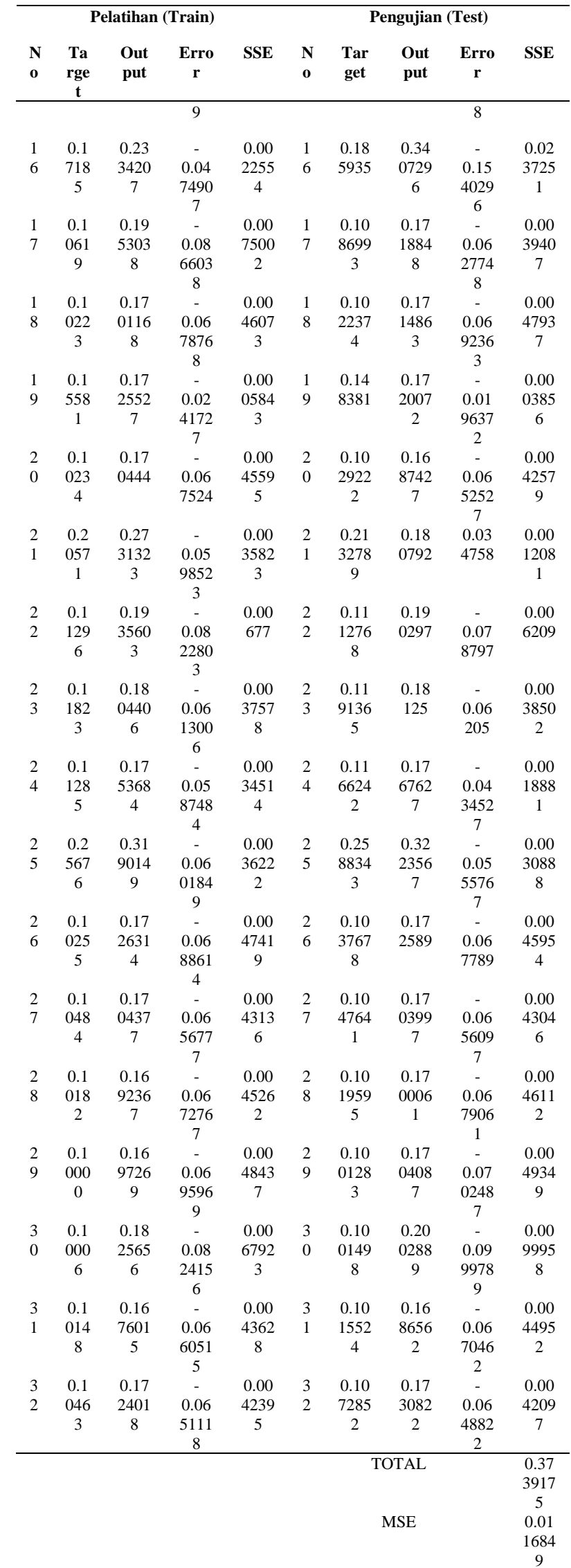

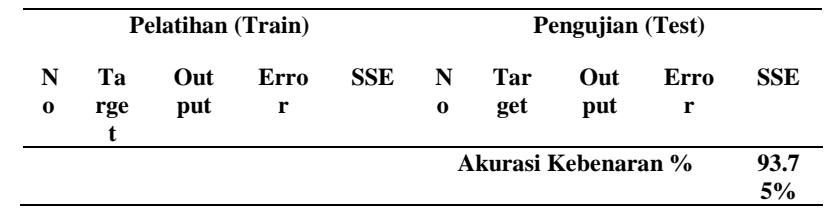

\subsubsection{Pelatihan dan Pengujian Arsitektur 7-32-1}

Berikut adalah hasil pengujian dengan 32 data pengujian dengan pola pengujian 32-1. Data hasil pengujian dan Pelatihan dapat dilihat pada tabel sebagai berikut:

Tabel 8. Hasil Pelatihan dan Pengujian dengan Model 7-32-1

\begin{tabular}{|c|c|c|c|c|c|c|c|c|c|}
\hline \multicolumn{5}{|c|}{ Pelatihan (Train) } & \multicolumn{5}{|c|}{ Pengujian (Test) } \\
\hline $\begin{array}{l}\mathbf{N} \\
\mathbf{o}\end{array}$ & $\begin{array}{l}\text { tar } \\
\text { get }\end{array}$ & $\begin{array}{c}\text { outp } \\
\text { ut }\end{array}$ & eror & sse & $\begin{array}{l}\mathbf{N} \\
\mathbf{o}\end{array}$ & $\begin{array}{c}\text { targ } \\
\text { et }\end{array}$ & $\begin{array}{l}\text { Out } \\
\text { put }\end{array}$ & Eror & sse \\
\hline \multirow[t]{3}{*}{1} & 0.1 & 0.16 & - & 0.003 & 1 & 0.10 & 0.16 & - & 0.002 \\
\hline & 05 & 4123 & 0.05 & 3319 & & 6395 & 0347 & 0.05 & 8620 \\
\hline & 28 & 11 & $\begin{array}{c}7723 \\
1\end{array}$ & 57 & & 5 & 82 & $\begin{array}{c}3497 \\
8\end{array}$ & 17 \\
\hline \multirow[t]{3}{*}{2} & 0.3 & 0.08 & 0.25 & 0.067 & 2 & 0.34 & 0.15 & 0.19 & 0.038 \\
\hline & 39 & 9470 & 8879 & 0184 & & 8347 & 2302 & 7157 & 8709 \\
\hline & 17 & 73 & 27 & 77 & & 49 & 9 & 1 & 23 \\
\hline \multirow[t]{3}{*}{3} & 0.2 & 0.11 & 0.10 & 0.010 & 3 & 0.21 & 0.11 & 0.09 & 0.009 \\
\hline & 14 & 2452 & 0247 & 0495 & & 2703 & 5296 & 8183 & 6399 \\
\hline & 11 & 78 & 22 & 06 & & 25 & 76 & 24 & 48 \\
\hline \multirow[t]{3}{*}{4} & 0.1 & 0.16 & - & 0.003 & 4 & 0.10 & 0.16 & - & 0.003 \\
\hline & 01 & 1651 & 0.05 & 3145 & & 4081 & 3226 & 0.05 & 4877 \\
\hline & 61 & 97 & 7572 & 32 & & 54 & 77 & $\begin{array}{c}9056 \\
8\end{array}$ & 02 \\
\hline \multirow[t]{4}{*}{5} & 0.1 & 0.15 & - & 0.002 & 5 & 0.10 & 0.16 & - & 0.003 \\
\hline & 08 & 8853 & 0.04 & 4475 & & 9382 & 5731 & 0.05 & 1038 \\
\hline & 44 & 06 & 9473 & 84 & & 18 & 82 & 5711 & 07 \\
\hline & & & 1 & & & & & 8 & \\
\hline \multirow[t]{3}{*}{6} & 0.1 & 0.11 & 0.08 & 0.007 & 6 & 0.19 & 0.12 & 0.07 & 0.005 \\
\hline & 98 & 2979 & 6470 & 4772 & & 9452 & 8030 & 4499 & 5502 \\
\hline & 65 & 18 & 82 & 04 & & 04 & 07 & 93 & 39 \\
\hline \multirow[t]{3}{*}{7} & 0.1 & 0.16 & - & 0.003 & 7 & 0.10 & 0.16 & - & 0.003 \\
\hline & 01 & 1083 & 0.05 & 4779 & & 2108 & 0668 & 0.05 & 3940 \\
\hline & 61 & 86 & $\begin{array}{c}8973 \\
9\end{array}$ & 16 & & 85 & 3 & $\begin{array}{c}8258 \\
3\end{array}$ & 29 \\
\hline \multirow[t]{3}{*}{8} & 0.1 & 0.13 & 0.02 & 0.000 & 8 & 0.16 & 0.13 & 0.04 & 0.001 \\
\hline & 66 & 9927 & 8942 & 8376 & & 8868 & 3387 & 1992 & 7633 \\
\hline & 33 & 06 & 94 & 94 & & 06 & 96 & 04 & 31 \\
\hline \multirow[t]{4}{*}{9} & 0.1 & 0.16 & - & 0.003 & 9 & 0.10 & 0.16 & - & 0.003 \\
\hline & 00 & 0251 & 0.05 & 4587 & & 1437 & 2075 & 0.06 & 6524 \\
\hline & 90 & 16 & 8811 & 53 & & 51 & 61 & 0435 & 63 \\
\hline & & & 2 & & & & & 6 & \\
\hline 1 & 0.1 & 0.16 & - & 0.002 & 1 & 0.10 & 0.16 & - & 0.002 \\
\hline \multirow[t]{2}{*}{0} & 06 & 0281 & 0.05 & 6575 & 0 & 8727 & 1469 & 0.04 & 4264 \\
\hline & 23 & 46 & $\begin{array}{c}1551 \\
5\end{array}$ & 53 & & 94 & 11 & $\begin{array}{c}9259 \\
1\end{array}$ & 59 \\
\hline 1 & 0.3 & 0.14 & 0.19 & 0.038 & 1 & 0.34 & 0.17 & 0.18 & 0.034 \\
\hline \multirow[t]{2}{*}{1} & 34 & 7864 & 6455 & 5946 & 1 & 4324 & 0901 & 5138 & 2761 \\
\hline & 21 & 82 & 18 & 36 & & 32 & 85 & 15 & 33 \\
\hline 1 & 0.4 & 0.40 & 0.07 & 0.005 & 1 & 0.47 & 0.40 & 0.05 & 0.003 \\
\hline \multirow[t]{2}{*}{2} & 54 & 2702 & 4267 & 5156 & 2 & 6974 & 8825 & 7894 & 3517 \\
\hline & 82 & 78 & 22 & 2 & & 21 & 8 & 2 & 39 \\
\hline 1 & 0.1 & 0.15 & - & 2.295 & 1 & 0.14 & 0.14 & 0.00 & 1.774 \\
\hline \multirow[t]{2}{*}{3} & 49 & 4520 & 0.00 & 29E- & 3 & 9730 & 8547 & 1332 & $96 \mathrm{E}-$ \\
\hline & 19 & 92 & $\begin{array}{c}4790 \\
9\end{array}$ & 05 & & 54 & 72 & 28 & 06 \\
\hline 1 & 0.7 & 0.57 & 0.30 & 0.095 & 1 & 0.88 & 0.64 & 0.25 & 0.066 \\
\hline \multirow[t]{2}{*}{4} & 84 & 3128 & 9651 & 8838 & 4 & 2776 & 2212 & 7787 & 4545 \\
\hline & 89 & 75 & 25 & 99 & & 14 & 12 & 88 & 93 \\
\hline 1 & 0.1 & 0.13 & 0.06 & 0.004 & 1 & 0.20 & 0.13 & 0.06 & 0.004 \\
\hline \multirow[t]{2}{*}{5} & 80 & 4835 & 7684 & 5812 & 5 & 2518 & 7597 & 6922 & 4786 \\
\hline & 52 & 01 & 99 & 58 & & 76 & 04 & 96 & 83 \\
\hline 1 & 0.1 & 0.16 & 0.02 & 0.000 & 1 & 0.18 & 0.13 & 0.05 & 0.002 \\
\hline 6 & 71 & 4173 & 1756 & 4733 & 6 & 5934 & 5857 & 0842 & 5849 \\
\hline & 85 & 99 & 01 & 24 & & 95 & 94 & 06 & 15 \\
\hline 1 & 0.1 & 0.16 & - & 0.002 & 1 & 0.10 & 0.15 & - & 0.002 \\
\hline 7 & 06 & 0635 & 0.05 & 6973 & 7 & 8699 & 9916 & 0.05 & 5813 \\
\hline & 19 & 88 & 1935 & 35 & & 3 & 58 & 0806 & 09 \\
\hline
\end{tabular}




\begin{tabular}{|c|c|c|c|c|c|c|c|c|c|}
\hline \multicolumn{5}{|c|}{ Pelatihan (Train) } & \multicolumn{5}{|c|}{ Pengujian (Test) } \\
\hline $\begin{array}{l}\mathbf{N} \\
\mathbf{0}\end{array}$ & $\begin{array}{l}\text { tar } \\
\text { get }\end{array}$ & $\begin{array}{c}\text { outp } \\
\text { ut }\end{array}$ & eror & sse & $\begin{array}{l}\mathbf{N} \\
\mathbf{0}\end{array}$ & $\begin{array}{c}\operatorname{targ} \\
\text { et }\end{array}$ & $\begin{array}{l}\text { Out } \\
\text { put }\end{array}$ & Eror & sse \\
\hline & & & 9 & & & & & 6 & \\
\hline 1 & 0.1 & 0.16 & - & 0.003 & 1 & 0.10 & 0.16 & - & 0.003 \\
\hline \multirow[t]{2}{*}{8} & 02 & 0618 & 0.05 & 4081 & 8 & 2237 & 0965 & 0.05 & 4475 \\
\hline & 23 & 99 & 8379 & 07 & & 42 & 42 & $\begin{array}{c}8715 \\
4\end{array}$ & 01 \\
\hline 1 & 0.1 & 0.14 & 0.00 & 3.804 & 1 & 0.14 & 0.12 & 0.02 & 0.000 \\
\hline \multirow[t]{2}{*}{9} & 55 & 2212 & 6167 & 3E- & 9 & 838 & 5022 & 7347 & 7479 \\
\hline & 81 & 1 & 9 & 05 & & 098 & 17 & 83 & 04 \\
\hline 2 & 0.1 & 0.16 & - & 0.003 & 2 & 0.10 & 0.15 & - & 0.003 \\
\hline \multirow[t]{2}{*}{0} & 02 & 0331 & 0.05 & 2960 & 0 & 2922 & 9735 & 0.05 & 1636 \\
\hline & 34 & 6 & $\begin{array}{c}7411 \\
6\end{array}$ & 92 & & 16 & 99 & 6246 & 12 \\
\hline 2 & 0.2 & 0.12 & 0.08 & 0.007 & 2 & 0.21 & 0.12 & 0.09 & 0.008 \\
\hline \multirow[t]{2}{*}{1} & 05 & 3900 & 9379 & 9886 & 1 & 3278 & 3079 & 2470 & 5507 \\
\hline & 71 & 9 & 1 & 24 & & 93 & 69 & 31 & 59 \\
\hline 2 & 0.1 & 0.17 & - & 0.003 & 2 & 0.11 & 0.16 & - & 0.002 \\
\hline \multirow[t]{2}{*}{2} & 12 & 0220 & 0.05 & 4740 & 2 & 1276 & 3097 & 0.05 & 6623 \\
\hline & 96 & 78 & $\begin{array}{c}8940 \\
8\end{array}$ & 15 & & 83 & 77 & $\begin{array}{c}1597 \\
8\end{array}$ & 29 \\
\hline 2 & 0.1 & 0.15 & - & 0.001 & 2 & 0.11 & 0.16 & - & 0.001 \\
\hline \multirow[t]{2}{*}{3} & 18 & 9629 & 0.04 & 6394 & 3 & 9136 & 0994 & 0.04 & 7467 \\
\hline & 23 & 81 & $\begin{array}{c}0489 \\
8\end{array}$ & 25 & & 45 & 46 & $\begin{array}{c}1794 \\
5\end{array}$ & 77 \\
\hline 2 & 0.1 & 0.15 & - & 0.001 & 2 & 0.11 & 0.16 & - & 0.000 \\
\hline \multirow[t]{2}{*}{4} & 12 & 7116 & 0.04 & 6399 & 4 & 6624 & 1627 & 0.02 & 8019 \\
\hline & 85 & 57 & $\begin{array}{c}0496 \\
6\end{array}$ & 72 & & 24 & 96 & 8318 & 07 \\
\hline 2 & 0.2 & 0.10 & 0.15 & 0.022 & 2 & 0.25 & 0.09 & 0.17 & 0.030 \\
\hline \multirow[t]{2}{*}{5} & 56 & 7479 & 1350 & 9068 & 5 & 8834 & 1463 & 5316 & 7357 \\
\hline & 76 & 87 & 13 & 62 & & 27 & 76 & 24 & 85 \\
\hline 2 & 0.1 & 0.16 & - & 0.003 & 2 & 0.10 & 0.16 & - & 0.003 \\
\hline \multirow[t]{2}{*}{6} & 02 & 0930 & 0.05 & 2673 & 6 & 3767 & 0920 & 0.05 & 1495 \\
\hline & 55 & 57 & $\begin{array}{c}7160 \\
6\end{array}$ & 31 & & 78 & 46 & $\begin{array}{c}6120 \\
5\end{array}$ & 06 \\
\hline 2 & 0.1 & 0.16 & - & 0.003 & 2 & 0.10 & 0.16 & - & 0.003 \\
\hline \multirow[t]{2}{*}{7} & 04 & 0678 & 0.05 & 1268 & 7 & 4764 & 0621 & 0.05 & 1171 \\
\hline & 84 & 59 & $\begin{array}{c}5918 \\
6\end{array}$ & 88 & & 11 & 85 & $\begin{array}{c}5831 \\
8\end{array}$ & 95 \\
\hline 2 & 0.1 & 0.16 & - & 0.003 & 2 & 0.10 & 0.16 & - & 0.003 \\
\hline \multirow[t]{2}{*}{8} & 01 & 0840 & 0.05 & 4669 & 8 & 1959 & 0765 & 0.05 & 4416 \\
\hline & 82 & 8 & $\begin{array}{c}8880 \\
8\end{array}$ & 49 & & 54 & 51 & $\begin{array}{c}8665 \\
5\end{array}$ & 42 \\
\hline 2 & 0.1 & 0.16 & - & 0.003 & 2 & 0.10 & 0.16 & - & 0.003 \\
\hline \multirow[t]{2}{*}{9} & 00 & 1121 & 0.06 & 7200 & 9 & 0128 & 0684 & 0.06 & 6632 \\
\hline & 00 & 85 & $\begin{array}{c}0991 \\
9\end{array}$ & 06 & & 31 & 61 & $\begin{array}{c}0524 \\
6\end{array}$ & 29 \\
\hline 3 & 0.1 & 0.15 & - & 0.003 & 3 & 0.10 & 0.16 & - & 0.003 \\
\hline \multirow[t]{2}{*}{0} & 00 & 5468 & 0.05 & 0601 & 0 & 0149 & 0599 & 0.06 & 6347 \\
\hline & 06 & 99 & 5319 & 9 & & 79 & 08 & $\begin{array}{c}0289 \\
1\end{array}$ & 73 \\
\hline 3 & 0.1 & 0.15 & - & 0.003 & 3 & 0.10 & 0.15 & - & 0.003 \\
\hline \multirow[t]{3}{*}{1} & 01 & 9551 & 0.05 & 3642 & 1 & 1552 & 9937 & 0.05 & 4020 \\
\hline & 48 & 74 & 8001 & 02 & & 41 & 23 & 8327 & 66 \\
\hline & & & 7 & & & & & 2 & \\
\hline 3 & 0.1 & 0.16 & - & 0.003 & 3 & 0.10 & 0.16 & - & 0.002 \\
\hline \multirow[t]{8}{*}{2} & 04 & 2086 & 0.05 & 0026 & 2 & 7285 & 0450 & 0.05 & 7301 \\
\hline & 63 & 38 & 4796 & 43 & & 17 & 94 & 2250 & 61 \\
\hline & & & 4 & & & & & 9 & \\
\hline & & & & & & & Total & & 0.263 \\
\hline & & & & & & & & & $\begin{array}{r}4752 \\
1\end{array}$ \\
\hline & & & & & & & MSE & & 0.008 \\
\hline & & & & & & & & & 2336 \\
\hline & & & & & & $\mathbf{A k u}$ & $\begin{array}{c}\text { i Keb } \\
\%\end{array}$ & aran & $\begin{array}{r}96.88 \\
\%\end{array}$ \\
\hline
\end{tabular}

\subsubsection{Pemilihan Arsitektur Terbaik Jaringan} Saraf Tiruan

Hasil software aplikasi Matlab R2011a yang digunakan untuk model arsitektur 7-4-1, arsitektur 78-1, arsitektur 7-16-1 dan arsitektur 7-32-1 adalah memperoleh pola arsitektur terbaik. Dari pola ini nanti akan digunakan untuk mempredikasi jumlah produksi telur ayam petelur. Penilaian model arsitektur terbaik dilihat dari beberapa aspek seperti epoch, error minimum dan akurasi kebenaran . Untuk lebih jelas dapat dilihat pada berikut :

Tabel 9. Rekapitulasi Model Arsitektur

\begin{tabular}{lcccc}
\hline Model & $7-4-1$ & $7-8-1$ & $7-16-1$ & $7-32-1$ \\
\hline Epochs & 1196 & 2963 & 380 & 252 \\
MSE & 0.010625 & 0.010995 & 0.0116849 & 0.0082336 \\
Akurasi & $96.88 \%$ & $96.88 \%$ & $93.75 \%$ & $96.88 \%$
\end{tabular}

Dari tabel 9 dapat dilihat bahwa model arsitektur terbaik yang akan digunakan untuk melakukan prediksi dari serangkaian uji coba model adalah 32-1 dengan epoch 252 , MSE 0,0082336 dan tingkat akurasi $96.88 \%$.

\section{Kesimpulan}

Berdasarkan hasil dan pembahasan diatas, maka penulis dapat mengambil kesimpulan sebagai berikut :

1. Setelah dilakukan percobaan dalam proses pelatihan dan pengujian sistem yang dilakukan dengan menggunakan software aplikasi Matlab R2011a Model Jaringan Syaraf Tiruan yang digunakan adalah 7-4-1, model 7-8-1, model 7-16-1 dan model 7-321, dapat diperoleh hasil yang baik dengan melihat MSE Pengujian yang terkecil adalah 7-32-1.

2. Dengan model arsitektur 32-1, dapat melakukan prediksi jumlah telur ayam petelur Berdasarkan Provinsi di indonesia dengan menunjukkan performa $96.88 \%$.

\section{DAFTAR PUSTAKA}

[1] Solikhun and M. Safii, "Jaringan Saraf Tiruan Untuk Memprediksi Tingkat Pemahaman Siswa terhadap Mata Pelajaran," J. Sains Komput. Inform., vol. 1, no. 1, pp. 24-36, 2017.

[2] S. Revi, Ramadan, Sari, "Model Jaringan Syaraf Tiruan Dalam Memprediksi Pendapatan Perkapita Masyarakat Perkotaan Pada Garis Kemiskinan Berdasarkan Propinsi," vol. 05, no. 02, pp. 122-135, 2018.

[3] A. Wanto, “Analisis Prediksi Indeks Harga Konsumen Berdasarkan Kelompok Kesehatan Dengan Menggunakan Metode Backpropagation," J. Penelit. Tek. Inform., vol. 2, no. 2, pp. 37-44, 2019.

[4] G. Dhaneswara, "Jaringan saraf tiruan 
propagasi balik untuk klasifikasi data," vol. 9, no. 3, pp. 117-131, 2004.

[5] D. O. (Faculty of I. E.-G. U. Maru'ao, "Neural Network Implementation in Foreign Exchange Kurs Prediction," 2010.

[6] A. Revi, "Jaringan Syaraf Tiruan Dalam Memprediksi Tingkat Pertumbuhan Industri Mikro Dan Kecil Berdasarkan Provinsi," Teknika, vol. 7, no. 2, 2018. 